\title{
Developing a shared understanding of the Upper Mississippi River: the foundation of an ecological resilience assessment
}

\author{
$\underline{\text { Kristen L. Bouska }}^{1}$, Jeffrey N. Houser ${ }^{1}$, Nathan R. De Jager $^{1}$ and Jon Hendrickson $^{2}$
}

\begin{abstract}
The Upper Mississippi River System(UMRS) is a large and complex floodplain river ecosystem that spans the jurisdictions of multiple state and federal agencies. In support of ongoing ecosystem restoration and management by this broad partnership, we are undertaking a resilience assessment of the UMRS. We describe the UMRS in the context of an ecological resilience assessment. Our description articulates the temporal and spatial extent of our assessment of the UMRS, the relevant historical context, the valued services provided by the system, and the fundamental controlling variables that determine its structure and function. An important objective of developing the system description was to determine the simplest, adequate conceptual understanding of the UMRS. We conceptualize a simplified UMRS as three interconnected subsystems: lotic channels, lentic off-channel areas, and floodplains. By identifying controlling variables within each subsystem, we have developed a shared understanding of the basic structure and function of the UMRS, which will serve as the basis for ongoing quantitative evaluations of factors that likely contribute to the resilience of the UMRS. As we undertake the subsequent elements of a resilience assessment, we anticipate our improved understanding of interactions, feedbacks, and critical thresholds will assist natural resource managers to better recognize the system's ability to adapt to existing and new stresses.
\end{abstract}

Key Words: Controlling variable; historical changes; large floodplain river

\section{INTRODUCTION}

As anthropogenic pressures increasingly affect ecosystems, there is growing interest in applying concepts of resilience to natural resource management (Benson and Garmestani 2011, Brown and Williams 2015). Resilience is defined as "the capacity to absorb disturbances and reorganize while undergoing change so as to still retain essentially the same function, structure, identity, and feedbacks" (Holling 1973, Walker et al. 2004:2). An important concept associated with this definition is that ecosystems are selforganizing, meaning that within limits, interactions and feedbacks maintain an ecosystem's state or regime (Levin 1998, Walker and Salt 2012). Disturbances or changes that move ecosystem components across critical thresholds can result in abrupt and unexpected shifts to alternate states that are subsequently maintained by novel interactions and feedbacks (Holling 1973, Gunderson 2000). Therefore, managing an ecosystem for resilience requires anticipation of critical thresholds, understanding feedbacks and interactions at different scales, and embracing variability and uncertainty (Allen et al. 2011).

The Upper Mississippi River System (UMRS) is a large and complex floodplain river ecosystem that spans the jurisdictions of multiple state and federal agencies. Ecologically, the system is diverse, supporting more than 140 fish species (Garvey et al. 2010) and serving as a continentally important migratory corridor for waterfowl (Beatty et al. 2015). Such high levels of biodiversity are thought to be supported by its hydrogeomorphic diversity and the associated diversity of physical, chemical, and biological conditions (De Jager and Rohweder 2012, De Jager and Houser 2016). There are strong differences in degrees of connectivity and biodiversity across the system. Cumulative inputs of nutrients and suspended sediments and the resulting sedimentation in off- channel areas have consequences across the entire system (WEST Consultants Inc. 2000). From a management perspective, five states, several federal agencies, and numerous local authorities are responsible for managing the river for a wide range of often conflicting uses (see flowchart in Fremling 2004:341). Many of these entities cooperate within the multiagency partnership that comprises the U.S. Army Corp of Engineers' (USACE) Upper Mississippi River Restoration Program (UMRR). The UMRR partnership includes the USACE, the U.S. Geological Survey (USGS), the U.S. Fish and Wildlife Service (USFWS), the U.S. Department of Agriculture, the U.S. Environmental Protection Agency, the U.S. Department of Transportation, and natural resource agencies from each of the five Upper Mississippi River (UMR) states, i.e., Minnesota, Wisconsin, Iowa, Illinois, and Missouri. No single agency can claim jurisdiction or management responsibility for the entire river system, and as a result, no single objective dominates management. Instead, management objectives have been developed for a wide range of geomorphic, hydraulic, biogeochemical, and biotic processes and end points (USACE 2011).

In its recently completed strategic plan, the UMRR adopted a vision for "a healthier and more resilient ecosystem that sustains the river's multiple uses" to guide its ecosystem restoration and monitoring activities (UMRR 2015:5). To support that vision, the UMRR partnership is undertaking a resilience assessment. Resilience assessment frameworks have been developed over the past decade to operationalize resilience concepts in the context of natural resource management (Quinlan et al. 2016). These frameworks emphasize that a resilience assessment should be framed around an integrated social-ecological system; however, because of constraints of the partnership agencies' authorities, expertise, and resources, we have limited our current assessment

${ }^{1}$ Upper Midwest Environmental Sciences Center, U.S. Geological Survey, La Crosse, WI, ${ }^{2}$ St. Paul District, U.S. Army Corps of Engineers, St. Paul, MN 
to the ecological system. Assessment frameworks provide a sequence of strategic questions that aid in developing a shared understanding of how a system functions and identifying the key controlling variables that influence ecosystem function and services (Resilience Alliance 2010, Walker and Salt 2012, O'Connell et al. 2015). Such assessments are meant to be an iterative learning process, whereby information gaps are identified and conceptual models are developed and updated with new information as it becomes available (Quinlan et al. 2016).

The available resilience assessment frameworks provide substantial guidance; however, there are few published applications of these frameworks from which to learn, particularly in natural resource management (Johnson et al. 2013). We share our system description for the UMRS developed in collaboration with partner agencies that describes the relevant historical changes and major management concerns for the UMRS and synthesizes our ecological understanding to identify critical controlling variables, defined as dominant factors believed to directly affect major resources at the river-floodplain reach scale. Given the complexity in ecosystem function and river management of the UMRS, an important objective of developing the system description was to determine the simplest, adequate conceptualization that reflects the fundamental nature of a large floodplain river. This broadly accepted description of the system is the first step in our resilience assessment and the foundation for the subsequent assessments of the ecological resilience of the UMRS.

\section{APPROACH}

In assessing the resilience of the UMRS, we have adapted available resilience assessment frameworks (Walker and Salt 2012, O'Connell et al. 2015) to our institutional and ecological constraints. The resulting framework consists of three primary elements: (1) system description, (2) assessing the system, and (3) adaptive governance and management. We focus on the system description and explain how it provides a foundation for the subsequent assessment elements. In developing this description we sought input from a "resilience working group," convened a partnership workshop, reviewed existing reports describing issues of management concern and objectives, and solicited review by representatives of various agencies of earlier drafts of this manuscript. The resilience working group was composed of representatives of three federal agencies (USACE, USGS, and USFWS) and each of the UMRS states. We hosted a three-day workshop with this group in January 2016, which was led by two facilitators with expertise in resilience concepts and applications. At this workshop, participants established a common understanding of ecological resilience and began identifying critical aspects of the system, including (1) the scale and boundaries of the system to be examined, (2) important historical changes to the system, (3) what is valued by users of the system, and (4) known drivers, controlling variables, and feedbacks. We relied on a substantial body of reports and publications that contain various descriptions of the UMRS, conceptual models of its structure and function, and management objectives (Lubinski 1993, Theiling et al. 2000, Lubinski and Barko 2003, USACE 2011). Further, an extensive review of ecological literature was conducted to further develop a concise description of the system focused on assessing its ecological resilience. Because of the large network of managers with UMRS responsibilities, we presented and sought feedback on our approach at several regional meetings.

\section{SYSTEM BOUNDARIES AND SCALE}

The UMRR is authorized to operate within the boundaries of the UMRS; therefore, our resilience assessment also uses the UMRS boundary to define the system. The UMRS is congressionally defined as the "commercially navigable portions of the Mississippi River main stem north of Cairo, Illinois" and commercially navigable tributaries, including the entire Illinois River (Water Resources Development Act of 1986, 33 U.S.C. $\S$ $\S 652)$. The UMRS comprises approximately 2000 river kilometers and adjacent floodplain lands. The importance of the UMRS as a multiple use natural resource is evident in its congressional recognition as a nationally significant transportation system and a nationally significant river ecosystem. Further, the UMR is highly valued for ecological, economic, recreational, and aesthetic uses and supports economic activities generating nearly $\$ 350$ billion annually along its corridor (Carlson 1999, USFWS 2015). The resilience working group agreed that the focal scale of the assessment should be the river-floodplain reach. The UMRS is commonly described as four river-floodplain reaches: the Upper Impounded Reach, the Lower Impounded Reach, the Unimpounded Reach, and the Illinois River Reach (Fig. 1; USACE 2011). Each floodplain reach has unique characteristics and is delineated based on aquatic vegetation, geomorphology, and the distribution of agricultural levees (Peck and Smart 1986, Lubinski 1993). Conditions in these reaches are influenced and constrained by processes and conditions at the larger catchment scales (see subsequent discussion of external drivers) and are also a product of the combined effects of processes and conditions occurring at smaller scales such as the navigation pools and individual aquatic areas, e.g., backwater lakes, side channels, and so forth.

Fig. 1. The Upper Mississippi River basin and floodplain reaches of the Upper Mississippi River System.

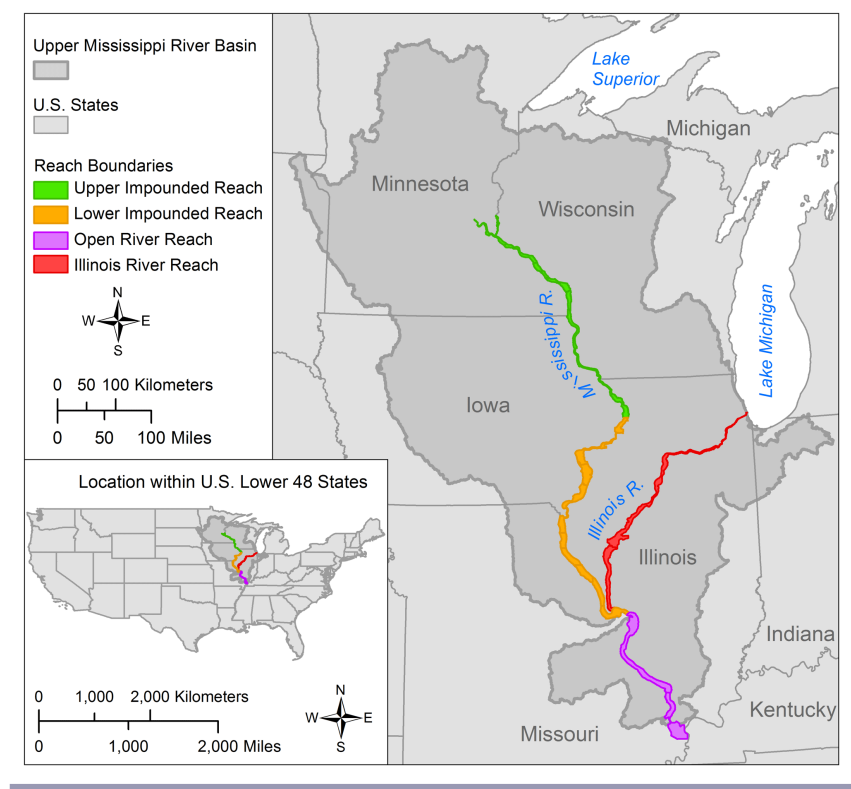


Fig. 2. A time line of historic changes to the Upper Mississippi River and its basin that have influenced the physical and ecological characteristics of the system.

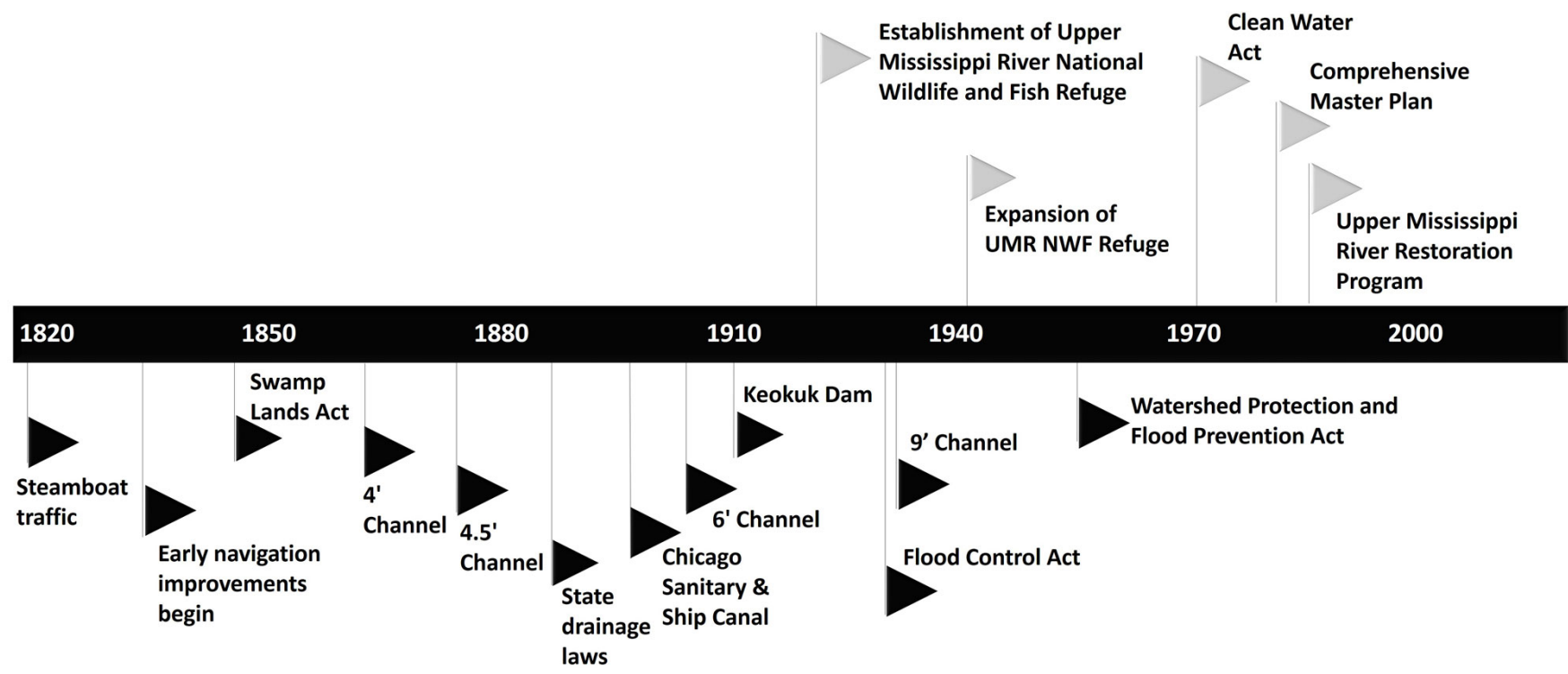

Forest clearing

Cultivation

Railroads built along river

Wetland and tile drainage

Levee construction

Channelization of tributaries and upland streams

Urban and industrial wastewater

Missouri River dams

Widespread use of fertilizer

\section{THE UPPER MISSISSIPPI RIVER: YESTERDAY AND TODAY}

Over the past 200 years, humans have significantly altered the physical and ecological condition of the UMRS (Fig. 2). As steamboat traffic grew during the 19th century, the need for large quantities of wood to fuel steamboats led to extensive deforestation (Norris 1997). Higher elevation prairies were rapidly converted to agriculture to support growing settlements (Nelson et al. 1994, Turner and Rabalais 2003). The 1850 Swamp Lands Act transferred more than $400 \mathrm{~km}^{2}$ of federally owned wetlands in the Mississippi River floodplain and an additional $30,000 \mathrm{~km}^{2}$ throughout the basin, upstream of the Missouri River confluence, to states for conversion into agricultural production (McCorvie and Lant 1993, Hey and Phillippi 1995). Between 1873 and 1891, drainage districts were created that allowed private landowners to organize agricultural improvement efforts, such as dredging and channelization of streams, installation of tile drainage, and construction of levees (McCorvie and Lant 1993).

Growing populations, water infrastructure, and changing land use throughout the basin degraded water quality. In 1900, the completion of the Chicago Sanitary and Ship Canal allowed
Chicago to discharge significant amounts of untreated sewage and industrial waste into the Illinois River (Karr et al. 1985). The 1972 Clean Water Act reduced the input of these and other pointsource pollutants to the river; however, the industrialization of agricultural practices and the post-World War II development of the fertilizer industry resulted in large increases in sediment and nutrient loads to the UMRS and Gulf of Mexico, having substantial effects on these ecosystems (Turner and Rabalais 2003). Though efforts to improve agricultural land use practices are growing (Natural Resources Conservation Service 2012), the agricultural dominance of the UMRS catchment land use continues to shape the condition of the river today (Turner and Rabalais 2003).

Modifications to improve navigability have profoundly changed the river. Early modifications included clearing snags, construction of wing dams, and blasting of shallow rapids near Des Moines and Rock Island (Dobney 1977, Anfinson 2003). Subsequent work to establish and maintain a progressively deeper navigation channel included construction of 2000 additional wing dams and closing dams, stabilization of nearly 200 miles of river bank with rock, extensive dredging, and 2 locks (Dobney 1977, 
Anfinson 2003, Fremling 2004). One of these locks and dams, built in 1913 at Keokuk, Iowa, included hydroelectric power generation and significantly reduced passage of migratory fishes (Fremling 2004). An upwelling of conservationists who sought to protect the remaining but quickly disappearing natural habitat along the river resulted in the establishment of the Upper Mississippi River Wildlife and Fish Refuge in 1924 (Meretsky et al. 2006, Anfinson 2003).

In 1930, Congress authorized the construction of a 2.7-m (9-ft.) navigation channel, requiring construction of 29 locks and dams between Minneapolis, Minnesota, and St. Louis, Missouri, and 8 on the Illinois River. Lock and dam structures established a minimum water surface elevation for navigation, resulting in inundation of approximately $630 \mathrm{~km}^{2}$ of floodplain between Minneapolis, Minnesota, and Cairo, Illinois, that now exist as large, shallow impoundments (Fremling 2004, De Jager et al. $2013 b$ ). Downstream of St. Louis, where locks and dams were not constructed, an additional 768 dikes and 224 revetments were constructed between 1930 and 1945 (Dobney 1977). Although effective for maintaining a deep channel for navigation, river training structures have reduced channel complexity and reduced the extent of low-velocity habitats (Shields 1995, WEST Consultants Inc. 2000). The effect of river training structures on flood stages in the Unimpounded Reach remains controversial (Remo et al. 2009, Watson et al. 2013). Even with navigation infrastructure, annual dredging in excess of 8 million metric tons per year continues throughout the system to maintain the navigation channel (WEST Consultants Inc. 2000, USACE 2016).

The Flood Control Acts of 1928 and 1936 authorized floodways and led to strengthened levees, modified channels, and cost sharing for structural projects on the Mississippi River downstream of Rock Island, Illinois (Dobney 1977, Myers and White 1993). Levee construction isolated large tracts of floodplain from the river and also contributed to increased flood levels and reduced flood storage capacity (WEST Consultants Inc. 2000, Remo et al. 2009). Subsequent flood-control legislation resulted in channelization of tens of thousands of miles of major tributaries and streams for flood abatement purposes (Brown 1974, Dobney 1977, Schoof 1980).

The cumulative effects of modifications to the basin, floodplain, and river have shaped the modern river's hydrogeomorphology, resulting in concerns regarding the current condition of the river. Land use changes have increased nutrient inputs that contribute to eutrophic conditions frequently observed throughout the system (Turner and Rabalais 2003, Houser and Richardson 2010). Land use changes have also increased sediment loads (Knox 2001) that have reduced water clarity, and, in combination with navigation infrastructure, resulted in high rates of sedimentation, loss of depth, and loss of spatial extent of low-velocity areas, such as backwaters and side channels (Bhowmik and Adams 1989, Bhowmik and Demissie 1989, WEST Consultants Inc. 2000). Large, shallow impoundments can suffer from increased winddriven wave action, resulting in increased turbidity and island erosion (WEST Consultants Inc. 2000). Loss of floodplain connectivity because of levees has eliminated the exchange of nutrients, organisms, and organic matter between river and floodplain environments that support biological diversity and productivity (Sparks 1995). The operation of the locks and dams have eliminated the seasonal low water levels that occurred prior to impoundment (Theiling and Nestler 2010). Levees, navigation infrastructure, extensive channel modifications of streams and rivers throughout the basin, and basin-wide land use changes, e.g., extensive tile drainage, have further modified flow regimes through increased discharge and water level variability (Sparks et al. 1998, Raymond et al. 2008, Schilling et al. 2010, Watson et al. 2013). Projections of increased precipitation and increased frequency of storm events and droughts will likely further influence flow regime (Pryor et al. 2013). For subsequent purposes, we classify these changes as external drivers that influence controlling variables, yet are ultimately external to, or operate at a larger scale, i.e., watershed and jurisdictional boundaries, than our focal scale, the riverfloodplain reach. We acknowledge that external drivers differ by floodplain reach, will remain within the system for the foreseeable future, and influence adaptive capacity.

\section{HOW DOES THE UPPER MISSISSIPPI RIVER SYSTEM FUNCTION?}

Critical to the structure and function of large floodplain rivers are fluxes of water and materials and movement of biota among the diverse aquatic and terrestrial areas that comprise the river and its floodplain (Ward et al. 1999, Opperman et al. 2010). These interactions occur across the diverse river-floodplain landscape and underpin high rates of biological diversity and productivity (Hein et al. 2003). To clearly identify the controlling variables within the UMRS ecosystem, we conceptualize the river as being composed of three interacting subsystems: lotic channels, lentic off-channel aquatic areas, and floodplains (Fig. 3). For example, lotic channels affect lentic off-channel areas through the rate of nutrient and sediment delivery. Lentic off-channel areas are hot spots of nutrient processing and biological production. Some of that biological production is subsequently returned to lotic environments as organic matter, phytoplankton, zooplankton, and invertebrates, which provide forage resources for organisms of higher trophic levels (Polis et al. 1997). Hydrologic connectivity sufficient to permit fish movement among these areas of the river and floodplain at appropriate times of the year is fundamental to support diverse fish communities that have different seasonal and ontogenetic habitat requirements (Galat and Zweimüller 2001). Complex mosaics of habitat in floodplain river environments further support terrestrial biota, including birds, mammals, reptiles, amphibians, and invertebrates (Robinson et al. 2002).

These three subsystems are distinguished by the combination of dominant controlling variables that structure ecosystem properties within each subsystem (Figs. 4-6). The lotic model describes those portions of the system that are dominated by substantial water flow and transport, primarily main and side channels. The lentic offchannel model describes backwater and floodplain lakes and wetlands, and the expansive impounded areas immediately upstream of lock and dams where factors such as depth, velocity, fetch, and water clarity are important drivers of local conditions. We consider floodplains to include the areas that experience intermittent inundation. In these areas, the extent and duration of inundation is a primary driver of local conditions (e.g., De Jager et al. 2015). Except in the Upper Impounded Reach, much of the historic floodplain has been disconnected from the river by levee construction, and this disconnection from the river is a fundamental change in the structure and function of those areas; however, we focus on ecological relationships in floodplains that remain actively connected to the river. 
Fig. 3. The Upper Mississippi River can be decomposed into three subsystems: lotic channels, lentic backwater lakes and impounded areas, and floodplains. Connectivity and exchange between subsystems is critical to the structure and function of large floodplain rivers. Curved arrows represent biogeochemical processing.

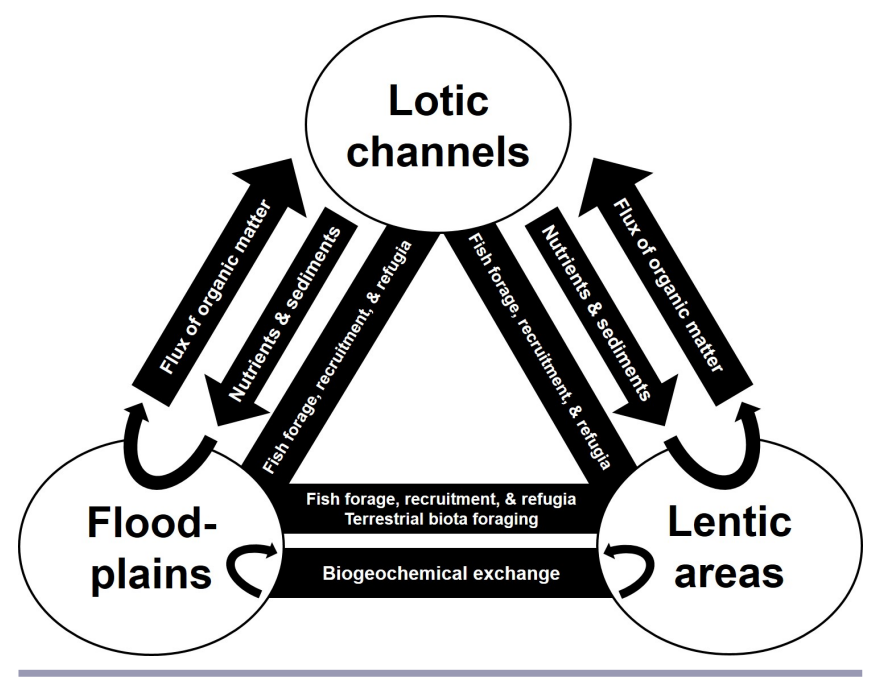

Fig. 4. A compilation of stakeholder uses and ecosystem services provided by the Upper Mississippi River and the major ecological resources, identified through workshop discussions, program reports, and management plans, which contribute to identified uses and services.

\begin{tabular}{|c|c|}
\hline 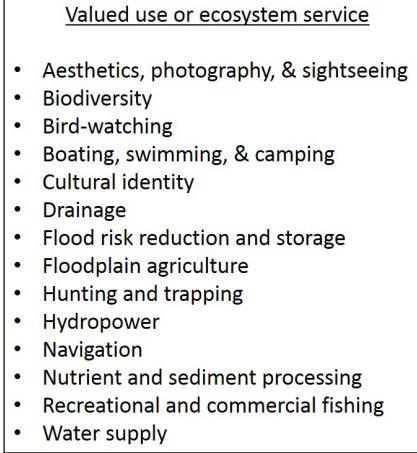 & $\begin{array}{l}\text { Major ecological resources } \\
\text { - Aquatic vegetation } \\
\text { - Birds } \\
\text { - Floodplain vegetation } \\
\text { - Native fish } \\
\text { - Wative mussels } \\
\text { - Waterfowl } \\
\text { Wuality }\end{array}$ \\
\hline
\end{tabular}

The following subsystem conceptual models are not meant to be a comprehensive description of the river system, but are intended as a simplified representation of each subsystem that identifies the key controlling variables and their primary roles in the structure and function of the ecosystem. In developing these conceptual models, we first synthesized output from a UMRS resilience workshop where a group of natural resource managers and scientists identified valued ecosystem services and management objectives throughout the system. Within each subsystem, we identified major resources required to support those valued ecosystem services or objectives (Fig. 4). Therefore, major resources (italicized subheadings) directly support popular uses of, and ecosystem services provided by, the river ecosystem and include water quality, native fish communities, native mussel communities, aquatic vegetation, waterfowl, floodplain vegetation, and avian communities. Controlling variables (underlined upon first use within each subsystem) are the dominant factors believed to directly affect major resources at the river-floodplain reach scale (Walker and Salt 2012) and are discussed relative to each major resource. As previously described, external drivers cause changes in controlling variables but are either external to or operate at larger scales than our focal scale and are one or more steps removed from the mechanisms through which major resources are directly affected.

\section{Lotic channels (Fig. 5)}

Water quality

Water quality is an important factor determining habitat suitability for riverine biota and for supporting a diversity of recreational and commercial uses (Figs. 4 and 5). Two components of water quality, total suspended solids (TSS) and nutrient concentrations are considered controlling variables in the lotic channels because of their extensive effects on river ecosystems (e.g., Hilton et al. 2006, Houser and Richardson 2010, Kjelland et al. 2015). High concentrations of TSS and nutrients in the lotic areas of the river result in high inputs to lentic, off-channel areas (see Lentic backwater lakes and impounded areas: Water quality), reduced aesthetic value, and increased water treatment costs for drinking water and industrial uses.

\section{Fish community}

Fish populations of the UMRS have diverse effects on the ecosystem through predation, bioturbation, and their role in the recruitment and dispersal of native mussels. UMRS fishes also support commercial and recreational fisheries and as such are an integral part of the social culture of the UMRS (e.g., Schramm and Ickes 2016). Fish use of lotic channels varies depending on species' life history requirements. Some species use channels as a migratory route to access seasonal habitats, other species reside in channels specifically for spawning and/or foraging, and rheophilic species tend to be year-round residents of the main channel (Dettmers et al. 2001a). To accommodate the diverse life history needs of persistent and seasonal residents, as well as opportunistic use by species typically associated with lentic areas, heterogeneity of depth and velocity within the riverine environment is essential (Galat and Zweimüller 2001).

This heterogeneity promotes diverse food webs that provide the range of forage resources required for a diverse fish community. Community structure of phytoplankton and zooplankton is strongly influenced by TSS and connectivity with lentic areas (Wahl et al. 2008, Burdis and Hoxmeier 2011, Manier 2014). Current velocity and substrate type within the channel influence the distribution of benthic invertebrates (Fremling 1960, Seagle et al. 1982, Anderson and Day 1986, Dettmers et al. 2001b), and connectivity with adjacent lentic areas provides important sources of invertebrate drift (Eckblad et al. 1984, Sheaffer and Nickum 1986b). Hydraulic traps within the river bedform, i.e., sand dunes, support the retention of macroinvertebrate drift (Gutreuter et al. 2006) and provide low-velocity refuge and energetic savings for fishes feeding on drift in the main channel (Lehtinen et al. 1997, Guensch et al. 2001, Wildhaber et al. 2003, Gaeuman and Jacobson 2007). Similarly, drift-feeding fishes have been observed to use areas 
Fig. 5. Major resources identified for lotic channels represent valued ecosystem services and include water quality, fish community, and mussel community. Nine controlling variables, or dominant factors, that affect major resources were identified to influence these major resources.

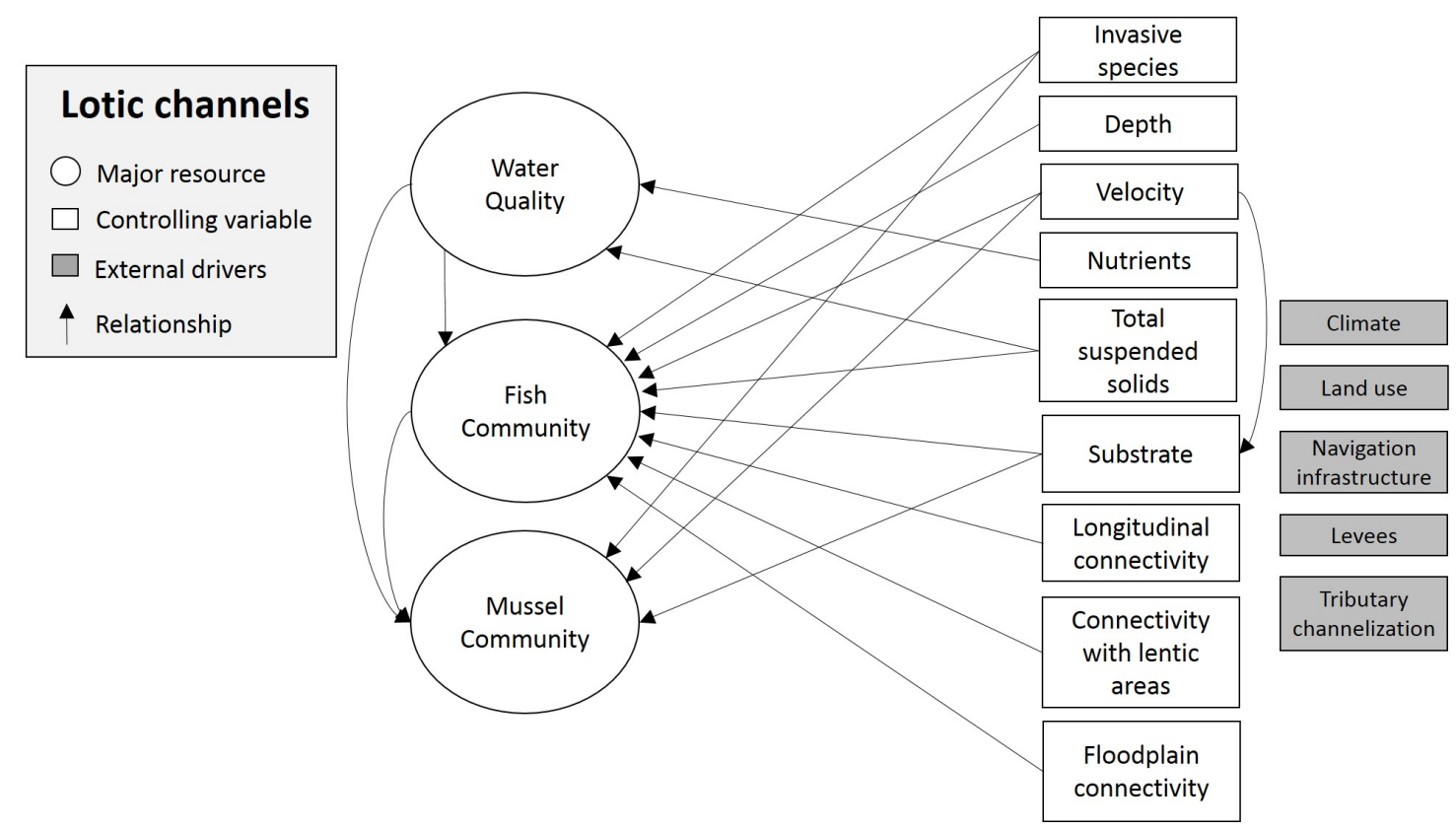

of reduced current velocity below sandbars, likely allowing them to maintain their position in a lower velocity environment while feeding on drift (Rosen et al. 1982).

Longitudinal connectivity of lotic channels and connectivity of lotic channels with lentic areas and floodplains benefit fish communities. Within the lotic channel, longitudinal connectivity provides access to spawning habitat and dispersal of buoyant eggs and drifting larvae to nursery habitats (Holland and Sylvester 1983, Holland 1986), yet can be fragmented by dams (Wilcox et al. 2004). Connectivity to off-channel areas and inundated floodplains is important for access to nursery environments (King et al. 2003, Schramm and Eggleton 2006, Schiemer and Hein 2008). Though many fluvial specialists and dependents, such as shovelnose sturgeon (Scaphirhynchus platorynchus) and paddlefish (Polyodon spathula), remain in the main channel throughout winter (Lubinski 1984, Sheehan et al. 1994, Quist et al. 1999, Zigler et al. 2003, Hurley et al. 2004), seasonal residents, such as freshwater drum (Aplodinotus grunniens), may leave channel environments to seek more favorable overwintering conditions elsewhere (Bodensteiner and Lewis 1992). During high flow events, lotic fishes commonly seek refuge in low-velocity areas.

Invasive species, including silver carp (Hypophthalmichthys molitrix) and bighead carp (Hypophthalmichthys nobilis), have become established in the Illinois River (Sass et al. 2010) and the Unimpounded (Williamson and Garvey 2005) and Lower Impounded Reaches of the UMR over the past 20 years (Chick and Pegg 2001). Their establishment has impacted native fish communities and food resources (Irons et al. 2007, Sass et al. 2014, Solomon et al. 2016).
Mussel community

Native freshwater mussels play an important role in the functioning of large river ecosystems through effects on nutrient and energy cycling that results from their substantial rates of water filtration and processing (Newton et al. 2011). In general, mussels have experienced a substantial, long-term decline because of historical, commercial exploitation, and periods of poor water quality (Tucker and Theiling 1999, Anthony and Downing 2001). Mussels are strongly affected by local hydrogeomorphic conditions, resulting in "patchy" spatial patterns (Ries et al. 2016). Mussels require substrate stability during high flow conditions and sufficient water velocity to transport oxygen, food, and waste materials during low flow conditions (Morales et al. 2006, Steuer et al. 2008, Zigler et al. 2008). Mussel recruitment relies on host fish species for dispersal during the veliger life stage; thus factors that impact fish distribution and abundance affect mussel communities. For example, Lock and Dam 19 is a significant barrier to fish migration and has prevented migratory fishes such as skipjack herring (Alosa chrysochloris), a host fish for the ebony shell (Fusconaia ebena), from accessing the river upstream of that dam (Kelner and Sietman 2000). Mussels are also affected by water quality. Historic industrial and domestic pollution led to mussel declines and extirpation, for example, in parts of the Illinois River (Starrett 1971), but partial recovery of mussel populations followed reductions in point-source pollution (Sietman et al. 2001). The invasive zebra mussel (Dreissena polymorpha) has become established throughout the UMRS (Cope et al. 1997) and likely influences native mussel communities (Tucker et al. 1993) and water quality (James et al. 2000) 
Fig. 6. Water quality, aquatic vegetation, fish community, mussel community, and waterfowl community represent the major resources of lentic backwater lakes and impounded areas. The nine controlling variables identified represent the major factors that influence major resource dynamics in the lentic subsystem.
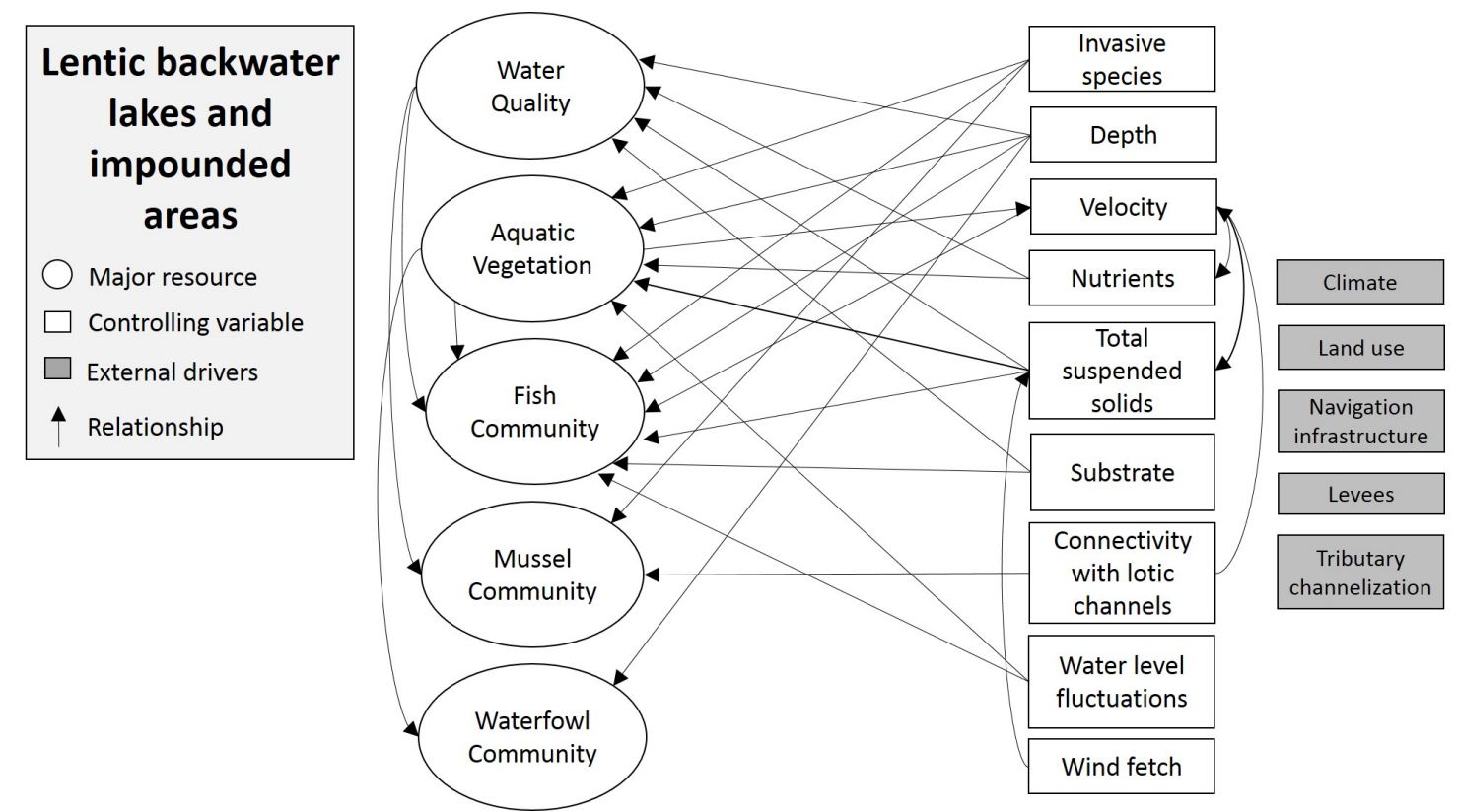

\section{Lentic backwater lakes and impounded areas (Fig. 6)}

Water quality

In lentic areas, water quality directly influences aquatic vegetation, fish, and mussels, and supports aesthetic and recreational uses (Figs. 4 and 6). As in the lotic subsystem, TSS and nutrients are considered controlling variables because of their effects on the structure and function of off-channel lentic areas. TSS is a primary determinant of the light environment and substantially affects the distribution of aquatic vegetation (see Aquatic vegetation). High nutrient concentrations in lentic areas are associated with thick mats of free-floating plants, e.g., duckweed, and filamentous algae, which can prevent light from reaching the water and is associated with reduced dissolved oxygen concentrations (Houser et al. 2013, Giblin et al. 2014). Dissolved oxygen and temperature are important water quality variables; they are not listed as key controlling variables in Figure 6 because they are largely determined by connectivity, velocity, and aquatic vegetation, all of which are included in the model and are functionally intermediate drivers of habitat suitability that are responding to the controlling variables contained in the model.

The construction and subsequent operation of the locks and dams on the impounded reaches of the UMR created extensive open water impounded areas and floodplain backwater lakes that remain connected by surface water to the main channel, even during summer low flow conditions. These lentic off-channel areas vary widely in their connectivity with lotic channels, which is determined by factors such as the number of surface water connections between the backwater and the channel and the size and orientation of those connections. The magnitude of surface water connectivity can affect water quality by determining the rate of delivery of nutrients and sediment (Richardson et al. 2004, De Jager and Houser 2012, Houser et al. 2013). For example, lessconnected backwaters have lower velocity, longer water residence time, lower nitrogen concentrations, higher temperatures, and lower dissolved oxygen concentrations than main channel environments (Sheaffer and Nickum 1986a, Bodensteiner and Lewis 1992, Knights et al. 1995). Less connected backwaters, especially those with extensive vegetation, often have lower TSS concentrations (Knowlton and Jones 2003, Pongruktham and Ochs 2015). However, shallow backwaters with scarce vegetation can exhibit high turbidity because of sediment resuspension similar to impounded areas (Sparks et al. 1990, Houser 2016). Depth affects water quality in backwater areas because deep backwater lakes may stratify, providing depth-dependent contrasts in velocity, temperature, and dissolved oxygen affecting habitat suitability during summer and winter (Gent et al. 1995, Johnson et al. 1998). Further, backwaters tend to accumulate organic sediments whose decomposition can result in oxygen depletion, thereby promoting phosphorus release from sediments (James et al. 1995).

\section{Aquatic vegetation}

During the growing season, aquatic vegetation provides structural cover for fish and invertebrates and forage resources for waterfowl, which are especially critical during spring and fall migration. Light availability is a critical factor in the distribution and abundance of submersed aquatic vegetation (Kimber et al. 1995, Korschgen et al. 1997, Kreiling et al. 2007, Moore et al. 2010). Light reaching the substrate and average water column light condition is determined by the combined effects of water depth 
and TSS (Kirk 1994). TSS is primarily affected by the transport of sediment from lotic channels and resuspension by wind and bioturbation. Wind fetch, common to impounded areas of the Upper Impounded Reach, produces high wave energy that resuspends sediments, increases TSS, and reduces light penetration (Owens and Crumpton 1995, Koch 2001). The feedbacks and interactions between vegetation abundance and turbidity because of sediment resuspension observed in shallow lakes (e.g., Scheffer and van Nes 2007) likely occur in the large, shallow impounded areas and backwaters of the UMRS (Sparks et al. 1990). Correlations suggesting interactions between TSS and macrophyte abundance have been observed within the UMRS (Sparks et al. 1990, Fischer and Claflin 1995, Theiling et al. 1996, Giblin 2017).

Aquatic vegetation species have varying velocity preferences that result in differences in community structure as a function of local current velocity (Peck and Smart 1986). High flow velocity and TSS during flood events can significantly affect the abundance and distribution of aquatic vegetation (Spink and Rogers 1996). Slow current velocity $(<0.01 \mathrm{~m} / \mathrm{s})$ enhances growth of many species of aquatic vegetation (Madsen et al. 2001). Emergent vegetation is generally restricted to shallow depths (generally $<1 \mathrm{~m}$ ) and low water velocities (Peck and Smart 1986). Duckweed and filamentous algae, which accumulate in areas of low velocity, shallow depth, and abundant nutrients, are common during midsummer in backwaters (Houser et al. 2013, Giblin et al. 2014) and can adversely affect both the aesthetics and the functioning of the ecosystem, i.e., reduced light availability and dissolved oxygen concentrations, when abundant.

Higher minimum water elevations and increased short-term water level fluctuations during the growing season because of dam operations can inhibit establishment of emergent vegetation and moist-soil plants (Sparks et al. 1998). Management efforts to reduce short-term water level fluctuations and minimum water elevations through the use of water level drawdowns have been associated with increased vegetation in parts of the river (Wlosinski et al. 2000), though vegetation response appears to vary with the composition in the seed bank (Kenow and Lyon 2009, Schorg 2014).

\section{Fish community}

Off-channel aquatic areas commonly provide fish spawning and nursery habitats (Holland 1986, Sheaffer and Nickum 1986a), diverse foraging resources, and refugia when low temperature, i.e., during winter, or high velocity conditions, i.e., during floods, exist in the main channel. Fishes use lentic areas for a variety of purposes, depending on their life history requirements. In late spring and summer, backwater habitats often have increased water residence time, low velocities, shallow depths, food resources, and warm temperatures that are important for growth and development of larval fish (Sheaffer and Nickum 1986a, Nannini et al. 2012). Backwaters generally support diverse phytoplankton, zooplankton, and macroinvertebrate communities that serve as important food sources for larval and adult fishes (Eckblad et al. 1984, Sheaffer and Nickum 1986b, Wahl et al. 2008, Burdis and Hoxmeier 2011, Ochs et al. 2013), though these food sources can be influenced by water level variability and substrate composition (Flinn et al. 2008). Submersed vegetation and other forms of structural complexity, such as coarse woody debris, provide protection from predation (Dewey et al. 1997) and promote growth
(Richardson et al. 1998) and abundance of certain young-of-year species (DeLain and Popp 2014). On the other hand, foraging of sight-feeding fish and reproductive success may be limited in backwaters with high suspended sediment concentrations (Kjelland et al. 2015).

During winter, as temperatures drop to $5-10^{\circ} \mathrm{C}$, many species seek out low-velocity backwater areas that allow minimal energy expenditure and provide protection from harsh conditions (Sheehan et al. 1994). Deep backwaters (depth $>1.2 \mathrm{~m}$ ) with velocity near zero generally exhibit adequate dissolved oxygen and temperature for centrarchid overwintering (Knights et al. 1995, Raibley et al. 1997). Conversely, during periods of low discharge in the summer, lentic fishes seek foraging opportunities in lotic channels (Gutreuter et al. 2010).

The invasive common carp (Cyprinus carpio), found throughout the UMRS, are well known to uproot aquatic vegetation and increase turbidity while foraging (Lubinski et al. 1986). At high biomass levels, common carp have exhibited negative impacts on both aquatic vegetation and waterfowl abundance in shallow lakes (Bajer et al. 2009) and likely have impacts on the native fish community through resource competition (Howell et al. 2014).

\section{Mussel community}

Lentic mussel communities exhibit greater diversity and abundance in areas well connected with lotic channels than in more isolated backwaters (Tucker et al. 1996, Zigler et al. 2008), likely because of oxygen requirements and transport of food and waste material, but they also may be influenced by sedimentation and pollutants in less connected backwaters. Adult and juvenile mussels may respond differently to the degree of connectivity between lentic and lotic areas, with some backwaters potentially serving as population sources and others as sinks (Ries et al. 2016).

\section{Waterfowl community}

The UMR is an important migratory corridor for waterfowl, which are highly valued for hunting and bird-watching activities. Waterfowl rely on lentic off-channel areas for feeding and resting during spring and fall migrations. Diving ducks are associated with expansive open areas, common to impounded areas, which support aquatic vegetation (Korschgen 1989). In the fall, diving ducks feed on submersed aquatic plants, including American wildcelery (Vallisneria americana; Korschgen et al. 1988), as well as invertebrates, including fingernail clams (Sphaeriidae; Thompson 1973). Dabbling ducks commonly forage in shallow wetlands, backwaters, and inundated floodplains that support moist-soil plants and invertebrates in spring and fall (Reid et al. 1989, Stafford et al. 2007). Areas where aquatic plants are absent or in low density have limited foraging value for waterfowl (Vonbank et al. 2016); however, dabbling ducks have responded well to restoration of aquatic vegetation (Dugger and Feddersen 2009, Hagy et al. 2017). Emergent vegetation and rooted floating aquatic vegetation also provide cover and food resources for locally nesting waterfowl (DeHaan 1999).

\section{Floodplains (Fig. 7)}

Water quality

Patterns of flood inundation directly impact the texture and nutrient availability of local floodplain soils (Hodges 1997, Yin 1998), which can further influence forest structure and 
Fig. 7. The major resources of the floodplain subsystem include water quality, vegetation community, and avian communities, which are known to be strongly influenced by flood inundation regimes, soils, and invasive species.
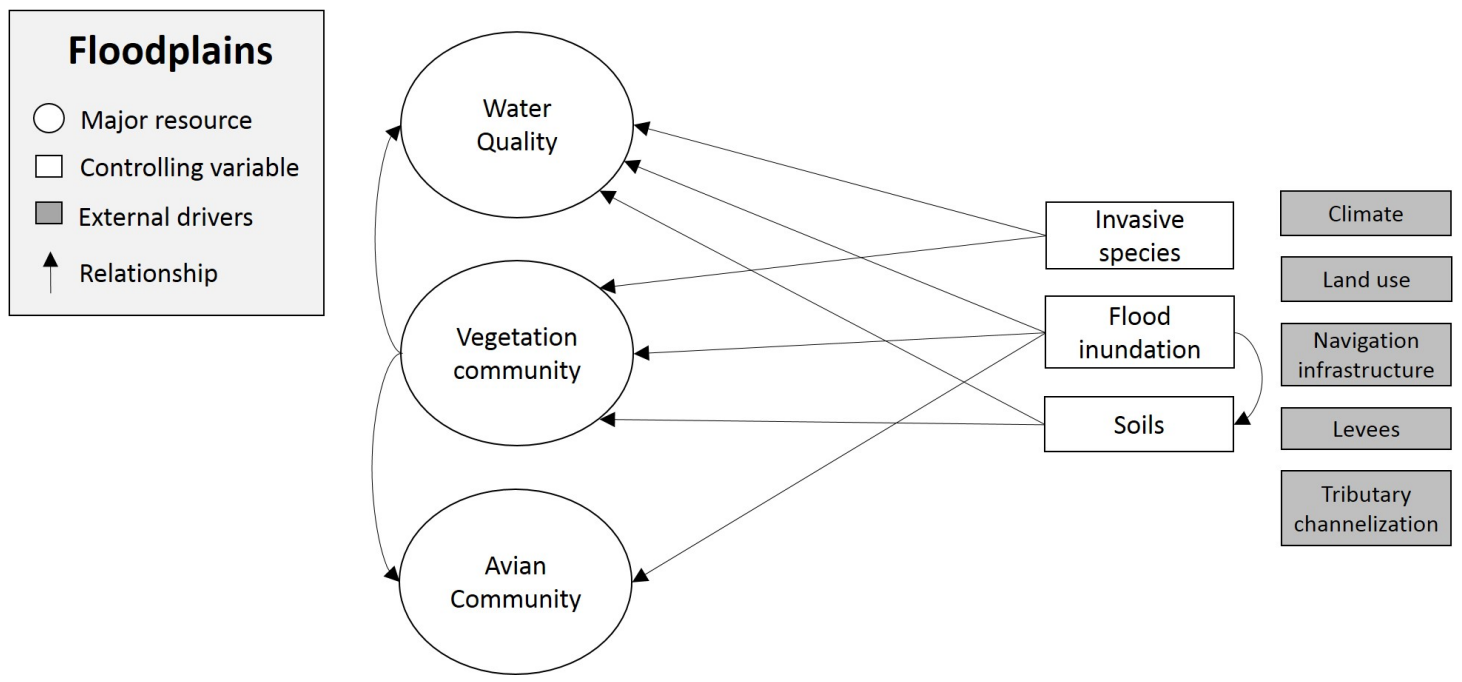

composition (Hosner and Minckler 1963) and alter nutrient cycling in ways that may impact river water quality (De Jager et al. 2012). Exchange of water between a river and its floodplain affects the transport and processing of sediments, nutrients, and organic matter (Tabacchi et al. 1998, Tockner et al. 1999, Noe and Hupp 2009). For example, flood pulses deposit fine particulate organic matter on floodplains and return dissolved organic carbon to the river (Grubaugh and Anderson 1989, Junk et al. 1989, Tockner et al. 1999). Floodplains are also known to have relatively high potential for denitrification, a microbial process by which nitrogen can be removed from the system (Pinay et al. 2000). Nutrient availability and cycling rates in the UMR are heavily influenced by temporal variation in water levels and associated anoxic conditions (De Jager et al. 2015, Kreiling et al. 2015), suggesting that changes in water levels could influence nutrient cycling (Cavanaugh et al. 2006).

\section{Vegetation community}

Floodplain vegetation includes a range of communities, including emergent marshes, wet meadows, grasslands, and floodplain forests. Flood inundation plays a fundamental role in the distribution of UMRS floodplain plant communities (De Jager et al. 2016), forest species distributions (De Jager et al. 2012), and forest age structure (De Jager 2012). Flood inundation is the manifestation of spatial and temporal variability in water and land surface elevation. Land surface elevation is largely determined by the net effects of erosion and sedimentation processes (Hodges 1997, Sluis and Tandarich 2004) but is likely also impacted by historic dredge material placement in the active floodplain (WEST Consultants Inc. 2000). Water surface elevation is controlled by the navigation infrastructure along the UMRS as well as watershed characteristics that impact runoff. Areas of lower land surface elevation experience more frequent inundation, greater flooding depths, and longer flood durations. These hydrologic variables directly affect vegetation by influencing the survival of different plant species and age classes (Hosner and Minckler 1963, Hodges 1997). For example, spatial variability in flood duration along the UMR floodplain creates a spatial mosaic of plant communities, where marsh communities are typically found in areas that flood more than 125 days per growing season and floodplain forests are rarely found in areas that flood for longer than 100 days per growing season (De Jager et al. 2016). Critical thresholds in the distribution of different forest tree species and age classes may also exist along the UMR floodplain. For example, a diverse array of tree species with a wide range of adaptations to inundation occur in areas that flood for less than 60 days per growing season, whereas only the most highly flood tolerant species occur in areas that flood for longer durations (De Jager et al. 2012). Furthermore, smaller tree seedlings and saplings are more easily overtopped during flooded conditions, and for this reason, the areas of more frequent and longer inundation durations tend to be dominated by older cohorts and lack evidence of understory regeneration (De Jager 2012).

Invasive species impact floodplain vegetation directly and by interacting with changes in the hydrologic regime. In the upper reaches of the river, reed canarygrass (Phalaris arundinacea) invades forest canopy gaps and suppresses the growth of tree seedlings (Thomsen et al. 2012); a number of possible interactions and positive feedbacks may be accelerating its spread. Largemagnitude flood events and high rates of herbivory on tree seedlings by white-tailed deer (Odocoileus virginianus) can further shift the balance toward reed canarygrass by causing high rates of tree mortality during early succession (De Jager et al. 2013a). Once established, reed canarygrass may alter soil nitrogen cycling in ways that further promote its growth and alter water quality (e.g., Green and Galatowitsch 2001, Swanson et al. 2017). Several additional invasive species also impact the vegetation of the UMRS but are less well studied, e.g., Japanese hops (Humulus japonicas), Japanese knotweed (Fallopia japonica), cucumber vine (Echinocystis lobata), and Black locust (Robinia pseudoacacia; Guyon et al. 2012). 
Table 1. Summary of the modern characteristics of the four floodplain reaches of the Upper Mississippi River System.

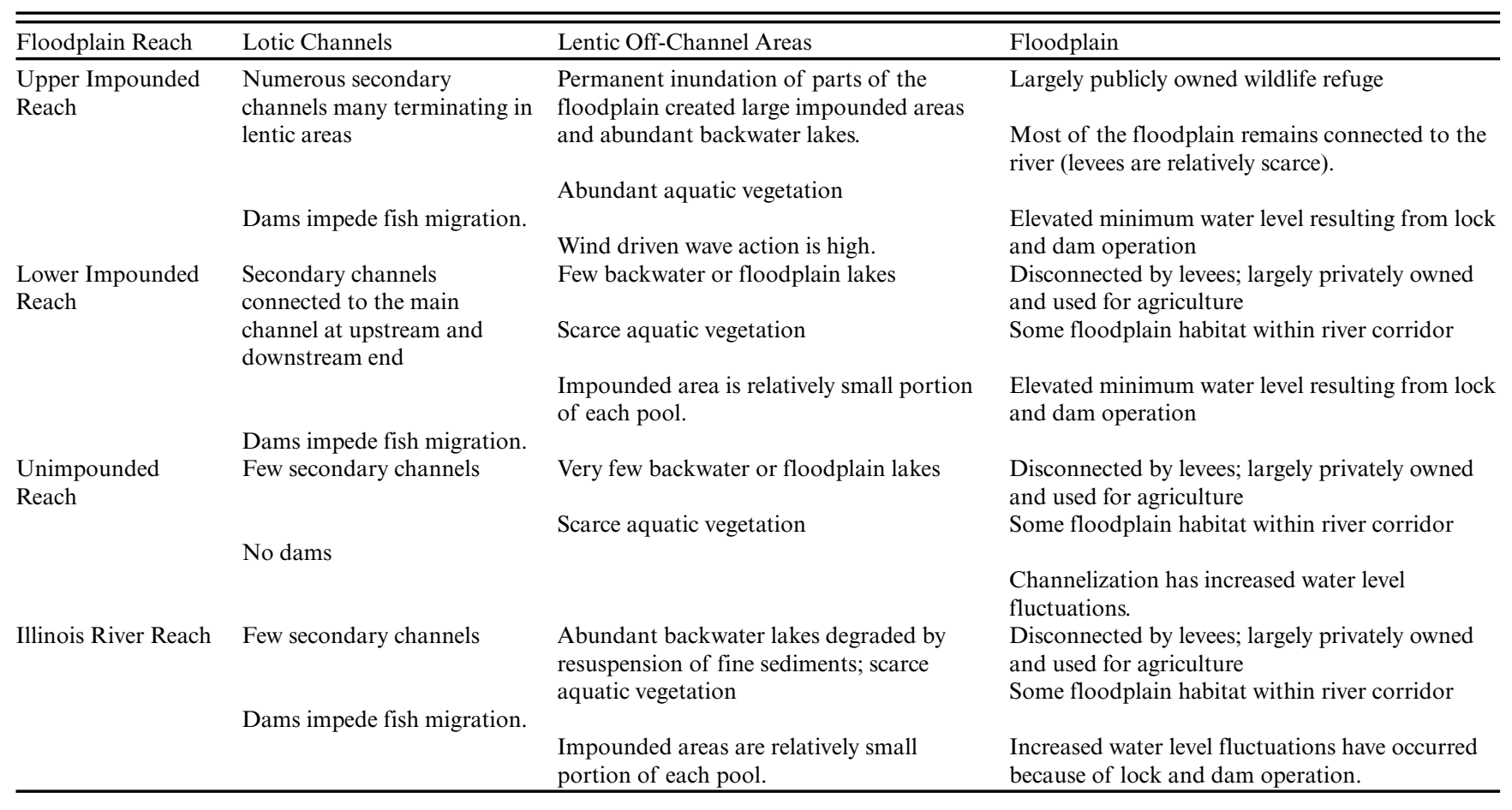

\section{Avian community}

The structure and composition of floodplain vegetation directly affects the avian community. During spring migration, trees within UMR floodplain forests commonly leaf out and flower early relative to upland areas, providing regionally important nesting and foraging habitat for migrating birds (Kirsch et al. 2013). Tree species-specific differences in leaf-out, flowering, and associated arthropod abundances create strong potential for variation in bird-tree species associations (Kirsch and Wellik 2017). Mature forests have greater tree species richness and structural diversity, as compared to young forests or more monotypic mature stands, and provide large dead snags that are critically important nesting habitats (Knutson et al. 2005). Hence, the lack of forest regeneration in some areas and shift toward more monotypic stands may impact the avian communities that utilize the floodplain. Further, seasonally inundated floodplains are important foraging habitat for shorebirds during spring and fall migration (Smith et al. 2012, Twedt 2013).

\section{TOWARD A RESILIENCE ASSESSMENT}

The system description we have presented reflects our emphasis on the ecosystem component of the larger social-ecological system. This focus largely reflects the authorities and expertise of the agencies within the UMRR partnership yet falls short of providing an integrated social-ecological system perspective, as recommended by resilience assessment frameworks. Implementing a social-ecological perspective would likely indicate additional factors that contribute to the resilience of that larger system and identify new opportunities for collaboration across various management agencies and stakeholders that have not be identified by solely focusing on ecological systems (Gunderson et al. 2017).
Even while largely restricting our system description to the ecosystem, applying the basic concepts of a resilience assessment have yielded benefits. For example, the emphasis on identifying a small number of controlling variables has made clear that though there are a diversity of interests along the river, many of those are affected by the same small number of controlling variables. Future discussions are intended to explore the implications of considering how management actions and restoration projects directly affect controlling variables and which relationships between controlling variables and major resources are most critical to better understand.

Because the latter phases of the UMRS resilience assessment are built from the system description and the overall assessment is intended to inform the restoration planning process, there was a strong need to codevelop a shared system description across the science and management communities. Given the numerous entities involved in river management with differing responsibilities and jurisdictions, the identification of major resources that reflect valued uses and agency objectives allowed us to identify a fairly limited number of controlling variables that are relevant to a variety of interests. Further, the focus on subsystems that were consistent across the four floodplain reaches, regardless of the distribution or abundance of that subsystem within any particular reach, assisted in developing a common understanding of the system. However, individuals did have concerns regarding the simplified representation of the system. Instead of arguing for one approach over another, we emphasized how the approaches differ and how they can be complementary. Although these discussions across the partner agencies required substantial time investments, the feedback greatly improved the present description, built ownership and 
Fig. 8. An example of the mosaic lotic channels, lentic areas, and floodplains for segments of the river that represent the four floodplain reaches. The orange hashed areas represent floodplains disconnected from the main channel by levees.

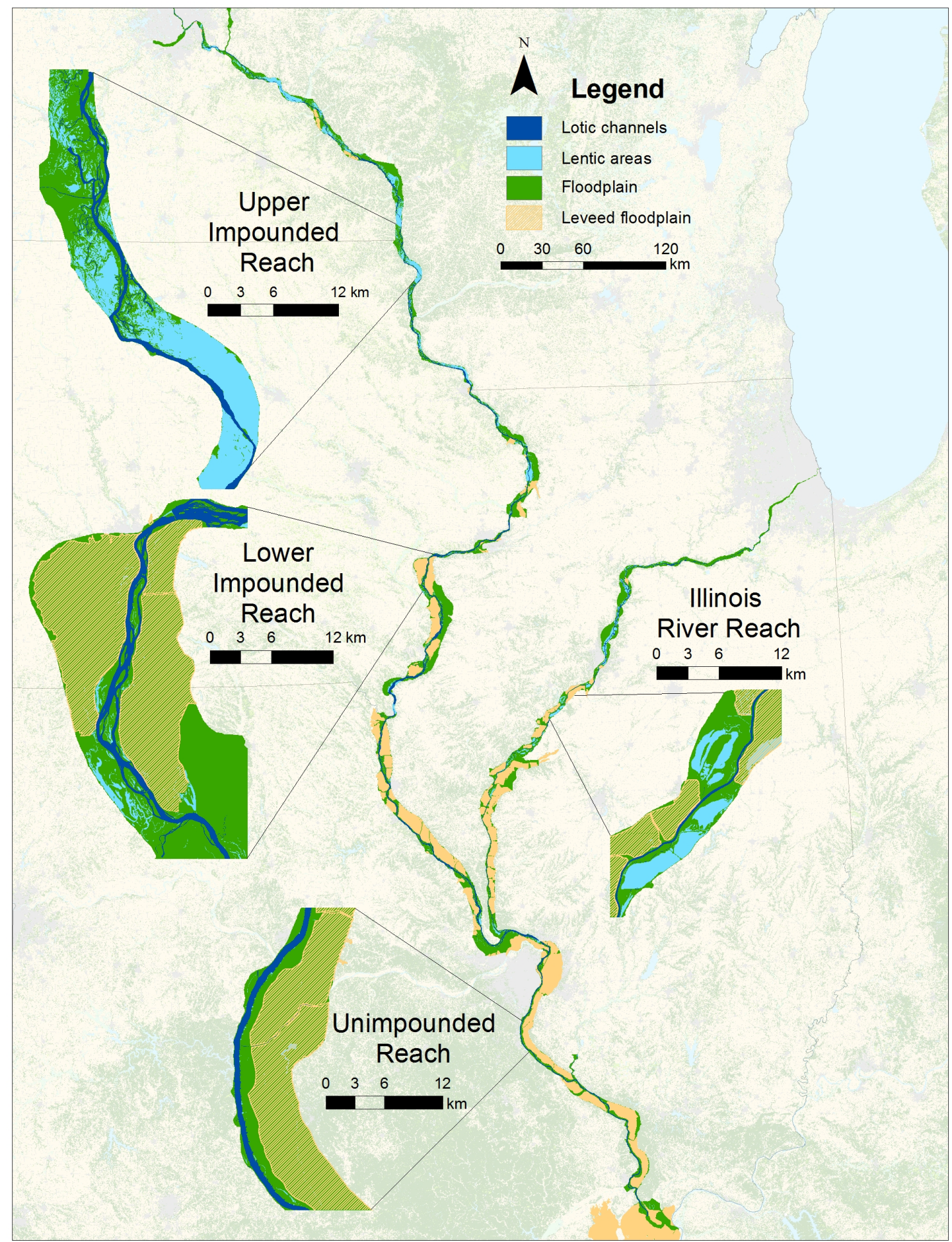


value for the assessment process, and facilitated stronger working relationships across the science and management personnel.

A primary objective of the UMRS system description is to distill a complex system to its fundamental parts to guide the ensuing elements of the resilience assessment. Importantly, there exists a spatially extensive, long-term data set for select elements of the UMRS (e.g., Johnson and Hagerty 2008). The identification of major resources, controlling variables, external drivers, and potential connections among them in our system description has provided a fresh perspective and new framework for analysis of the data as an important component of the resilience assessment. If analysis of the data suggests management-relevant feedback loops and potential thresholds, we can refine our conceptual models. Further, conceptualizing the four UMRS floodplain reaches as simplified mosaics of three subsystems makes clear the substantial differences in the abundance and distribution of, and connections among, subsystems across the four floodplain reaches (Table 1, Fig. 8). These contrasts in geomorphology and connectivity among reaches are currently being considered in the context of specific principles, i.e., maintain diversity and redundancy, manage connectivity, and manage slow variables and feedbacks, that have been proposed for enhancing the coping capacity of ecosystems to environmental change (Biggs et al. 2012). Further, future work could evaluate the role of various restoration actions on the identified controlling variables to better understand how these actions contribute to resilience in the riverfloodplain reaches.

More broadly, our simplified conceptualization of the UMRS as three interacting subsystems and their components may be applicable to other large floodplain rivers. The application of resilience concepts to the UMRS is an opportunity to improve our understanding of the structure and function of large floodplain rivers, identify management strategies that influence the coping capacity of large river systems, and enhance the application of resilience assessments in natural resource management.

Responses to this article can be read online at: http://www.ecologyandsociety.org/issues/responses. php/10014

\footnotetext{
Acknowledgments:

We thank Lance Gunderson and Allyson Quinlan for facilitating our initial resilience workshop. We acknowledge the resilience working group members who have contributed to our understanding of the system: Dave Bierman, Andy Casper, Bob Clevenstine, Shawn Giblin, Dave Herzog, Marvin Hubbell, Kirsten Mickelsen, Nate Richards, Sarah Schmuecker, and Steve Winter. We also thank Karen Hagerty, Jeff Janvrin, Ken Lubinski, Teresa Newton, Levi Solomon, Sara Strassman, and Chuck Theiling for review of earlier drafts of this manuscript. Additionally, we thank the numerous individuals within the broader Upper Mississippi River Restoration Program partnership who provided feedback at regional meetings, e.g., Long Term Resource Monitoring Science Meeting, Upper Mississippi River Conservation Committee Annual Meeting, Upper Mississippi River Restoration Coordinating Committee Quarterly
}

Meeting, and Upper Mississippi River Basin Association Quarterly Meeting. The work was funded as part of the U.S. Army Corps of Engineers' Upper Mississippi River Restoration Program. Use of trade, product, or firm names does not imply endorsement by the $U$. S. government.

\section{LITERATURE CITED}

Allen, C. R., G. S. Cumming, A. S. Garmestani, P. D. Taylor, and B. H. Walker. 2011. Managing for resilience. Wildlife Biology 17 (4):337-349. http://dx.doi.org/10.2981/10-084

Anderson, R. V., and D. M. Day. 1986. Predictive quality of macroinvertebrate - habitat associations in lower navigation pools of the Mississippi River. Hydrobiologia 136:101-112. http:// dx.doi.org/10.1007/BF00051507

Anfinson, J. O. 2003. The river we have wrought: a history of the Upper Mississippi. University of Minnesota Press, Minneapolis, Minnesota, USA.

Anthony, J. L., and J. A. Downing. 2001. Exploitation trajectory of a declining fauna: a century of freshwater mussel fisheries in North America. Canadian Journal of Fisheries and Aquatic Sciences 58(10):2071-2090. http://dx.doi.org/10.1139/f01-130

Bajer, P. G., G. Sullivan, and P. W. Sorensen. 2009. Effects of a rapidly increasing population of common carp on vegetative cover and waterfowl in a recently restored Midwestern shallow lake. Hydrobiologia 632(1):235-245. http://dx.doi.org/10.1007/ s10750-009-9844-3

Beatty, W. S., E. B. Webb, D. C. Kesler, L. W. Naylor, A. H. Raedeke, D. D. Humburg, J. M. Coluccy, and G. J. Soulliere. 2015. An empirical evaluation of landscape energetic models: mallard and American black duck space use during the non-breeding period. Journal of Wildlife Management 79:1141-1151. http://dx. doi.org/10.1002/jwmg.920

Benson, M. H., and A. S. Garmestani. 2011. Can we manage for resilience? The integration of resilience thinking into natural resource management in the United States. Environmental Management 48:392-399. http://dx.doi.org/10.1007/s00267-011-9693-5

Bhowmik, N. G., and J. R. Adams. 1989. Successional changes in habitat caused by sedimentation in navigation pools. Hydrobiologia 176:17-27. http://dx.doi.org/10.1007/BF00026540

Bhowmik, N. G., and M. Demissie. 1989. Sedimentation in the Illinois River valley and backwater lakes. Journal of Hydrology 105(1-2):187-195. http://dx.doi.org/10.1016/0022-1694(89)90103-0

Biggs, R., M. Schlüter, D. Biggs, E. L. Bohensky, S. BurnSilver, G. Cundill, V. Dakos, T. M. Daw, L. S. Evans, K. Kotschy, A. M. Leitch, C. Meek, A. Quinlan, C. Raudsepp-Hearne, M. D. Robards, M. L. Schoon, L. Schultz, and P. C. West. 2012. Toward principles for enhancing the resilience of ecosystem services. Annual Review of Environment and Resources 37:421-448. http:// dx.doi.org/10.1146/annurev-environ-051211-123836

Bodensteiner, L. R., and W. M. Lewis. 1992. Role of temperature, dissolved oxygen, and backwaters in the winter survival of freshwater drum (Aplodinotus grunniens) in the Mississippi River. Canadian Journal of Fisheries and Aquatic Sciences 49:173-184. http://dx.doi.org/10.1139/f92-021 
Brown, J. P. 1974. Stream channelization: the economics of the controversy. Natural Resources Journal 14(4):557-576.

Brown, E. D., and B. K. Williams. 2015. Resilience and resource management. Environmental Management 56:1416-1427. http:// dx.doi.org/10.1007/s00267-015-0582-1

Burdis, R. M., and R. J. H. Hoxmeier. 2011. Seasonal zooplankton dynamics in main channel and backwater habitats of the Upper Mississippi River. Hydrobiologia 667:69-87. http:// dx.doi.org/10.1007/s10750-011-0639-y

Carlson, B. D. 1999. Multi-use management on the Upper Mississippi River system: public preferences for future management actions. Thesis. University of Minnesota, Minneapolis, Minnesota, USA.

Cavanaugh, J. C., W. B. Richardson, E. A. Strauss, and L. A. Bartsch. 2006. Nitrogen dynamics in sediment during water level manipulation on the Upper Mississippi River. River Research and Applications 22:651-666. http://dx.doi.org/10.1002/rra.926

Chick, J. H., and M. A. Pegg. 2001. Invasive carp in the Mississippi River basin. Science 292(5525):2250-2251. http://dx.doi. org/10.1126/science.292.5525.2250

Cope, W. G., M. R. Bartsch, and R. R. Hayden. 1997. Longitudinal patterns in abundance of the zebra mussel (Dreissena polymorpha) in the Upper Mississippi River. Journal of Freshwater Ecology 12(2):235-238. http://dx.doi. org/10.1080/02705060.1997.9663531

DeHaan, L. T. 1999. Habitat selection by mallard broods on Navigation Pool 7 of the Upper Mississippi River. Thesis. Saint Mary's University, Winona, Minnesota, USA.

De Jager, N. R. 2012. Effects of flood frequency and duration on the allometry of community-level stem size-density distributions in a floodplain forest. American Journal of Botany 99 (9):1572-1576. http://dx.doi.org/10.3732/ajb.1200169

De Jager, N. R., B. J. Cogger, and M. A. Thomsen. $2013 a$. Interactive effects of flooding and deer (Odocoileus virginianus) browsing on floodplain forest recruitment. Forest Ecology and Management 303:11-19. http://dx.doi.org/10.1016/j.foreco.2013.02.028

De Jager, N. R., and J. N. Houser. 2012. Variation in watermediated connectivity influences patch distributions of total $\mathrm{N}$, total $\mathrm{P}$, and TN:TP ratios in the Upper Mississippi River, USA. Freshwater Science 31(4):1254-1272. http://dx.doi.org/10.1899/12-035.1

De Jager, N. R., and J. N. Houser. 2016. Patchiness in a large floodplain river: associations among hydrology, nutrients, and fish communities. River Research and Applications 32:1915-1926. http://dx.doi.org/10.1002/rra.3026

De Jager, N. R., and J. J. Rohweder. 2012. Spatial patterns of aquatic habitat richness in the Upper Mississippi River floodplain, USA. Ecological Indicators 13:275-283. http://dx.doi. org/10.1016/j.ecolind.2011.06.013

De Jager, N. R., J. J. Rohweder, and J. C. Nelson. 2013b. Past and predicted future changes in the land cover of the Upper Mississippi River floodplain, USA. River Research and Applications 29:608-618. http://dx.doi.org/10.1002/rra.1615
De Jager, N. R., J. J. Rohweder, Y. Yin, and E. Hoy. 2016. The Upper Mississippi River floodscape: spatial patterns in flood inundation and associated plant community distributions. Applied Vegetation Science 19(1):164-172. http://dx.doi. org/10.1111/avsc.12189

De Jager, N. R., W. Swanson, E. A. Strauss, M. Thomsen, and Y. Yin. 2015. Flood pulse effects on nitrification in a floodplain forest impacted by herbivory, invasion, and restoration. Wetlands Ecology and Management 23:1067-1081. http://dx.doi.org/10.1007/ $\underline{\text { s11273-015-9445-Z }}$

De Jager, N. R., M. Thomsen, and Y. Yin. 2012. Threshold effects of flood duration on the vegetation and soils of the Upper Mississippi River floodplain, USA. Forest Ecology and Management 270:135-146. http://dx.doi.org/10.1016/j.foreco.2012.01.023

DeLain, S. A., and W. A. Popp 2014. Relationship of weed shiner and young-of-year bluegill and largemouth bass abundance to submersed aquatic vegetation in Navigation Pools 4, 8, and 13 of the Upper Mississippi River, 1998-2012. Long Term Resource Monitoring Program Technical Report 2014-T001. U.S. Geological Survey, Reston, Virginia, USA.

Dettmers, J. M., S. Gutreuter, D. H. Wahl, and D. A. Soluk. 2001a. Patterns in abundance of fishes in main channels of the upper Mississippi River system. Canadian Journal of Fisheries and Aquatic Sciences 58(5):933-942. http://dx.doi.org/10.1139/ $\underline{\mathrm{f} 01-046}$

Dettmers, J. M., D. H. Wahl, D. A. Soluk, and S. Gutreuter. $2001 b$. Life in the fast lane: fish and foodweb structure in the main channel of large rivers. Journal of the North American Benthological Society 20(2):255-265. http://dx.doi.org/10.2307/1468320

Dewey, M. R., W. B. Richardson, and S. J. Zigler. 1997. Patterns of foraging and distribution of bluegill sunfish in a Mississippi River backwater: influence of macrophytes and predation. Ecology of Freshwater Fish 6:8-15. http://dx.doi.org/10.1111/ j.1600-0633.1997.tb00137.x

Dobney, F. J. 1977. River engineers on the Middle Mississippi: a history of the St. Louis District, U.S. Army Corps of Engineers. U.S. Government Printing Office, Washington, DC, USA.

Dugger, B. D., and J. C. Feddersen. 2009. Using river flow management to improve wetland habitat quality for waterfowl on the Mississippi River, USA. Wildfowl 59:62-74.

Eckblad, J. W., C. S. Volden, and L. S. Weilgart. 1984. Allochthonous drift from backwaters to the main channel of the Mississippi River. American Midland Naturalist 111(1):16-22. http://dx.doi.org/10.2307/2425537

Fischer, J. R., and T. O. Claflin. 1995. Declines in aquatic vegetation in Navigation Pool No. 8, upper Mississippi River between 1975 and 1991. River Research and Applications 11 (2):157-165. http://dx.doi.org/10.1002/rrr.3450110205

Flinn, M. B., S. R. Adams, M. R. Whiles, and J. E. Garvey. 2008. Biological responses to contrasting hydrology in backwaters of Upper Mississippi River Navigation Pool 25. Environmental Management 41:468-486. http://dx.doi.org/10.1007/s00267-008-9078-6 
Fremling, C. R. 1960. Biology and possible control of nuisance caddisflies of the Upper Mississippi River. Iowa State University, Ames, Iowa, USA.

Fremling, C. R. 2004. Immortal river: the Upper Mississippi in ancient and modern times. The University of Wisconsin Press, Madison, Wisconsin, USA.

Gaeuman, D., and R. B. Jacobson. 2007. Quantifying fluid and bed dynamics for characterizing benthic physical habitat in large rivers. Journal of Applied Ichthylogy 23(4):359-364. http://dx.doi. org/10.1111/j.1439-0426.2007.00888.x

Galat, D. L., and I. Zweimüller. 2001. Conserving large-river fishes: is the highway analogy an appropriate paradigm? Journal of the North American Benthological Society 20(2):266-279. http:// dx.doi.org/10.2307/1468321

Garvey, J., B. Ickes, and S. Zigler. 2010. Challenges in merging fisheries research and management: the Upper Mississippi River experience. Hydrobiologia 640:125-144. http://dx.doi.org/10.1007/ s10750-009-0061-X

Gent, R., J. Pitlo, Jr., and T. Boland. 1995. Largemouth bass response to habitat and water quality rehabilitation in a backwater of the Upper Mississippi River. North American Journal of Fisheries Management 15:784-793. http://dx.doi.org/10.1577/1548-8675 (1995)015<0784:LBRTHA>2.3.CO;2

Giblin, S. M. 2017. Identifying and quantifying environmental thresholds for ecological shifts in a large semi-regulated river. Journal of Freshwater Ecology 32:433-453. http://dx.doi. org/10.1080/02705060.2017.1319431

Giblin, S. M., J. N. Houser, J. F. Sullivan, H. A. Langrehr, J. T. Rogala, and B. D. Campbell. 2014. Thresholds in the response of free-floating plant abundance to variation in hydraulic connectivity, nutrients, and macrophyte abundance in a large floodplain river. Wetlands 34:413-425. http://dx.doi.org/10.1007/ $\underline{\mathrm{s} 13157-013-0508-8}$

Green, E. K., and S. M. Galatowitsch. 2001. Differences in wetland plant community establishment with additions of nitrate$\mathrm{N}$ and invasive species (Phalaris arundinacea and Typha $\times$ glauca). Canadian Journal of Botany 79:170-178. http://dx.doi. org/10.1139/b00-157

Grubaugh, J. W., and R. V. Anderson. 1989. Upper Mississippi River: seasonal and floodplain forest influences on organic matter transport. Hydrobiologia 174:235-244. http://dx.doi.org/10.1007/ $\underline{\mathrm{BF} 00008163}$

Guensch, G. R., T. B. Hardy, and R. C. Addley. 2001. Examining feeding strategies and position choice of drift-feeding salmonids using an individual-based mechanistic foraging model. Canadian Journal of Fisheries and Aquatic Sciences 58(3):446-457. http:// dx.doi.org/10.1139/f00-257

Gunderson, L. H. 2000. Ecological resilience - in theory and application. Annual Review of Ecology and Systematics 31:425-439. http://dx.doi.org/10.1146/annurev.ecolsys.31.1.425

Gunderson, L., B. A Cosens, B. C. Chaffin, C. A. (T.) Arnold, A. K. Fremier, A. S. Garmestani, R. K. Craig, H. Gosnell, H. E. Birge, C. R. Allen, M. H. Benson, R. R. Morrison, M. C. Stone, J. A. Hamm, K. Nemec, E. Schlager, and D. Llewellyn. 2017. Regime shifts and panarchies in regional scale social-ecological water systems. Ecology and Society 22(1):31. http://dx.doi. org/10.5751/ES-08879-220131

Gutreuter, S., J. M. Vallaza, and B. C. Knights. 2006. Persistent disturbance by commercial navigation alters the relative abundance of channel-dwelling fishes in a large river. Canadian Journal of Fisheries and Aquatic Sciences 63:2418-2433. http://dx. doi.org/10.1139/f06-129

Gutreuter, S., J. M. Vallazza, and B. C. Knights. 2010. Lateral distribution of fishes in the main-channel trough of a large floodplain river: implications for restoration. River Research and Applications 26(5):619-635. http://dx.doi.org/10.1002/rra.1271

Guyon, L., C. Deutsch, J. Lundh, and R. Urich. 2012. Upper Mississippi River systemic forest stewardship plan. U.S. Army Corps of Engineers, Washington, DC, USA.

Hagy, H. M., C. S. Hine, M. M. Horath, A. P. Yetter, R. V. Smith, and J. D. Stafford. 2017. Waterbird response indicates floodplain wetland restoration. Hydrobiologia 804:119-137. http://dx.doi. org/10.1007/s10750-016-3004-3

Hein, T., C. Baranyi, G. J. Herndl, W. Wanek, and F. Schiemer. 2003. Allochthonous and autochthonous particulate organic matter in floodplains of the River Danube: the importance of hydrological connectivity. Freshwater Biology 48(2):220-232. http://dx.doi.org/10.1046/j.1365-2427.2003.00981.x

Hey, D. L., and N. S. Phillippi. 1995. Flood reduction through wetland restoration: the Upper Mississippi River basin as a case history. Restoration Ecology 3(1):4-17. http://dx.doi.org/10.1111/ j.1526-100X.1995.tb00070.x

Hilton, J., M. O'Hare, M. J. Bowes, and J. I. Jones. 2006. How green is my river? A new paradigm of eutrophication in rivers. Science of the Total Environment 365(1-3):66-83. http://dx.doi. org/10.1016/j.scitotenv.2006.02.055

Hodges, J. D. 1997. Development and ecology of bottomland hardwood sites. Forest Ecology and Management 90:117-125. http://dx.doi.org/10.1016/S0378-1127(96)03906-0

Holland, L. E. 1986. Distribution of early life history stages of fishes in selected pools of the Upper Mississippi River, Pool 7. Hydrobiologia 136(1):121-130. http://dx.doi.org/10.1007/BF00051509

Holland, L. E., and J. R. Sylvester. 1983. Distribution of larval fishes related to potential navigation impacts on the Upper Mississippi River. Transactions of the American Fisheries Society 112:293-301. http://dx.doi.org/10.1577/1548-8659(1983)112<293: DOLFRT $>2.0 . \mathrm{CO} ; 2$

Holling, C. S. 1973. Resilience and stability of ecological systems. Annual Review of Ecology and Systematics 4:1-23. http://dx.doi. org/10.1146/annurev.es.04.110173.000245

Hosner, J. F., and L. S. Minckler. 1963. Bottomland hardwood forests of southern Illinois-regeneration and succession. Ecology 44(1):29-41. http://dx.doi.org/10.2307/1933178

Houser, J. N. 2016. Contrasts between channels and backwaters in a large, floodplain river: testing our understanding of nutrient cycling, phytoplankton abundance, and suspended solids dynamics. Freshwater Science 35(2):457-473. http://dx.doi. org/10.1086/686171 
Houser, J. N., S. M. Giblin, W. F. James, H. A. Langrehr, J. T. Rogala, J. F. Sullivan, and B. R. Gray. 2013. Nutrient cycling, connectivity and free-floating plant abundance in backwater lakes of the Upper Mississippi River. River Systems 21(1):71-89. http:// dx.doi.org/10.1127/1868-5749/2013/0080

Houser, J. N., and W. B. Richardson. 2010. Nitrogen and phosphorus in the Upper Mississippi River: transport, processing, and effects on the river ecosystem. Hydrobiologia 640 (1):71-88. http://dx.doi.org/10.1007/s10750-009-0067-4

Howell, J. M., M. J. Weber, and M. L. Brown. 2014. Evaluation of trophic niche overlap between native fishes and young-of-theyear common carp. American Midland Naturalists 172:91-106. http://dx.doi.org/10.1674/0003-0031-172.1.91

Hurley, K. L., R. J. Sheehan, R. C. Heidinger, P. S. Wills, and B. Clevenstine. 2004. Habitat use by middle Mississippi River pallid sturgeon. Transactions of the American Fisheries Society 133:1033-1041. http://dx.doi.org/10.1577/T03-042.1

Irons, K. S., G. G. Sass, M. A. McClelland, and J. D. Stafford. 2007. Reduced condition factor of two native fish species coincident with invasion of non-native Asian carps in the Illinois River, U.S.A. Is this evidence for competition and reduced fitness? Journal of Fish Biology 71:258-273. http://dx.doi.org/10.1111/ j.1095-8649.2007.01670.x

James, W. F., J. W. Barko, M. Davis, H. L. Eakin, J. T. Rogala, and A. C. Miller. 2000. Filtration and excretion by zebra mussels: implications for water quality impacts in Lake Pepin, upper Mississippi River. Journal of Freshwater Ecology 15(4):429-437. http://dx.doi.org/10.1080/02705060.2000.9663764

James, W. F., J. W. Barko, and H. L. Eakin. 1995. Internal phosphorus loading in Lake Pepin, upper Mississippi River. Journal of Freshwater Ecology 10(3):269-276. http://dx.doi. org/10.1080/02705060.1995.9663446

Johnson, B. L., and K. H. Hagerty. 2008. Long term resource monitoring program: status and trends of selected resources of the Upper Mississippi River system. U.S. Geological Survey, La Crosse, Wisconsin, USA.

Johnson, B. L., B. C. Knights, J. W. Barko, R. F. Gaugush, D. M. Soballe, and W. F. James. 1998. Estimating flow rates to optimize winter habitat for centrarchid fish in Mississippi River (USA) backwaters. River Research and Applications 14(6):499-510. http:// dx.doi.org/10.1002/(SICI)1099-1646(1998110)14:6<499::AIDRRR516>3.0.CO;2-I

Johnson, F. A., B. K. Williams, and J. D. Nichols. 2013. Resilience thinking and a decision-analytic approach to conservation: strange bedfellows or essential partners? Ecology and Society 18 (2):27. http://dx.doi.org/10.5751/ES-05544-180227

Junk, W. J., P. B. Bayley, and R. E. Sparks. 1989. The flood pulse concept in river-floodplain systems. Canadian Special Publication of Fisheries and Aquatic Sciences 106(1):110-127.

Karr, J. R., L. A. Toth, and D. R. Dudley. 1985. Fish communities of midwestern rivers: a history of degradation. BioScience 35 (2):90-95. http://dx.doi.org/10.2307/1309845

Kelner, D. E., and B. E. Sietman. 2000. Relic populations of the ebony shell, Fusconaia ebena (Bivalvia: Unionidae), in the upper
Mississippi River drainage. Journal of Freshwater Ecology 15 (3):371-377. http://dx.doi.org/10.1080/02705060.2000.9663755

Kenow, K. P., and J. E. Lyon. 2009. Composition of the seed bank in drawdown areas of Navigation Pool 8 of the Upper Mississippi River. River Research and Applications 25(2):194-207. http://dx. doi.org/10.1002/rra.1118

Kimber, A., J. L. Owens, and W. G. Crumpton. 1995. Light availability and growth of wildcelery (Vallisneria americana) in upper Mississippi River backwaters. River Research and Applications 11:167-174. http://dx.doi.org/10.1002/rrr.3450110206

King, A. J., P. Humphries, and P. S. Lake. 2003. Fish recruitment on floodplains: the roles of patterns of flooding and life history characteristics. Canadian Journal of Fisheries and Aquatic Sciences 60(7):773-786. http://dx.doi.org/10.1139/f03-057

Kirk, J. T. O. 1994. Light and photosynthesis in aquatic ecosystems. Cambridge University Press, Cambridge, United Kingdom. http://dx.doi.org/10.1017/CBO9780511623370

Kirsch, E. M., P. J. Heglund, B. R. Gray, and P. Mckann. 2013. Songbird use of floodplain and upland forests along the Upper Mississippi River corridor during spring migration. Condor 115 (1):115-130. http://dx.doi.org/10.1525/cond.2012.110209

Kirsch, E. M., and M. J. Wellik. 2017. Tree species preferences of foraging songbirds during spring migration in floodplain forests of the Upper Mississippi River. American Midland Naturalist 177: 226-249. http://dx.doi.org/10.1674/0003-0031-177.2.226

Kjelland, M. E., C. M. Woodley, T. M. Swannack, and D. L. Smith. 2015. A review of the potential effects of suspended sediment on fishes: potential dredging-related physiological, behavioral, and transgenerational implications. Environment Systems and Decisions 35(3):334-350. http://dx.doi.org/10.1007/ $\underline{\text { s10669-015-9557-2 }}$

Knights, B. C., B. L. Johnson, and M. B. Sandheinrich. 1995. Responses of bluegills and black crappies to dissolved oxygen, temperature, and current in backwater lakes of the upper Mississippi River during winter. North American Journal of Fisheries Management 15:390-399. http://dx.doi.org/10.1577/1548-8675 (1995) $015<0390:$ ROBABC $>2.3$. CO 2

Knowlton, M. F., and J. R. Jones. 2003. Connectivity influences temporal variation of limnological conditions in Missouri River scour lakes. Lake and Reservoir Management 19(2):160-170. http://dx.doi.org/10.1080/07438140309354082

Knox, J. C. 2001. Agricultural influence on landscape sensitivity in the Upper Mississippi River valley. Catena 42(2-4):193-224. http://dx.doi.org/10.1016/S0341-8162(00)00138-7

Knutson, M. G., L. E. McColl, and S. A. Suarez. 2005. Breeding bird assemblages associated with stages of forest succession in large river floodplains. Natural Areas Journal 25(1):55-69.

Koch, E. W. 2001. Beyond light: physical, geological, and geochemical parameters as possible submersed aquatic vegetation habitat requirements. Estuaries 24(1):1-17. http://dx.doi. org/10.2307/1352808

Korschgen, C. E. 1989. Riverine and deepwater habitats for diving ducks. Pages 157-180 in L. M. Smith, R. L. Pederson, and R. M. 
Kaminski, editors. Habitat management for migrating and wintering waterfowl in North America. Texas Tech University Press, Lubbock, Texas, USA.

Korschgen, C. E., L. S. George, and W. L. Green 1988. Feeding ecology of canvasbacks staging on Pool 7 of the upper Mississippi River. Pages 237-249 in M. W. Weller, editor. Waterfowl in winter. University of Minnesota Press, Minneapolis, Minnesota, USA.

Korschgen, C. E., W. L. Green, and K. P. Kenow. 1997. Effects of irradiance on growth and winter bud production by Vallisneria americana and consequences to its abundance and distribution. Aquatic Botany 58(1):1-9. http://dx.doi.org/10.1016/S0304-3770 (97)00014-4

Kreiling, R. M., N. R. De Jager, W. Swanson, E. A. Strauss, and M. A. Thomsen. 2015. Effects of flooding on ion exchange rates in an Upper Mississippi River floodplain forest impacted by herbivory, invasion, and restoration. Wetlands 35:1005-1012. http://dx.doi.org/10.1007/s13157-015-0675-x

Kreiling, R. M., Y. Yin, and D. T. Gerber. 2007. Abiotic influences on the biomass of Vallisneria americana Michx. in the Upper Mississippi River. River Research and Applications 23:343-349. http://dx.doi.org/10.1002/rra.984

Lehtinen, R. M., N. D. Mundahl, and J. C. Madejczyk. 1997. Autumn use of woody snags by fishes in backwater and channel border habitats of a large river. Environmental Biology of Fishes 49(1):7-19. http://dx.doi.org/10.1023/A:1007346430221

Levin, S. A. 1998. Ecosystems and the biosphere as complex adaptive systems. Ecosystems 1:431-436. http://dx.doi.org/10.1007/ $\underline{\mathrm{s} 100219900037}$

Lubinski, K. S. 1984. Winter diving surveys of main channel microhabitats and fish populations in Mississippi River reaches subjected to thalweg disposal. Illinois Natural History Survey, Grafton, Illinois, USA.

Lubinski, K. S. 1993. A conceptual model of the Upper Mississippi River system ecosystem. Long Term Resource Monitoring Program Technical Report 93-T 001. U.S. Fish and Wildlife Service, Onalaska, Wisconsin, USA.

Lubinski, K. S., and J. W. Barko 2003. Upper Mississippi River Illinois waterway system navigation feasibility study. Environmental Science Panel Report. U.S. Army Corps of Engineers.

Lubinski, K. S., A. Van Vooren, G. Farabee, J. Janecek, and S. D. Jackson. 1986. Common carp in the Upper Mississippi River. Hydrobiologia 136:141-153. http://dx.doi.org/10.1007/BF00051511

Madsen, J. D., P. A. Chambers, W. F. James, E. W. Koch, and D. F. Westlake. 2001. The interaction between water movement, sediment dynamics and submersed macrophytes. Hydrobiologia 444:71-84. http://dx.doi.org/10.1023/A:1017520800568

Manier, J. 2014. Spatial and temporal dynamics of phytoplankton assemblages in selected reaches of the Upper Mississippi River: Navigation pools 8, 13, and 26. Thesis. University of WisconsinLa Crosse, La Crosse, Wisconsin, USA.

McCorvie, M. R., and C. L. Lant. 1993. Drainage district formation and the loss of midwestern wetlands, 1850-1993. Agricultural History 67(4):13-39.
Meretsky, V. J., R. L. Fischman, J. R. Karr, D. M. Ashe, M. J. Scott, R. F. Noss, and R. L. Schroeder. 2006. New directions in conservation for the National Wildlife Refuge System. BioScience 56(2):135-143. http://dx.doi.org/10.1641/0006-3568(2006)056[0135: NDICFT]2.0.CO;2

Moore, M., S. P. Romano, and T. Cook. 2010. Synthesis of Upper Mississippi River System submersed and emergent aquatic vegetation: past, present, and future. Hydrobiologia 640 (1):103-114. http://dx.doi.org/10.1007/s10750-009-0062-9

Morales, Y., L. J. Weber, A. E. Mynett, and T. J. Newton. 2006. Effects of substrate and hydrodynamic conditions on the formation of mussel beds in a large river. Journal of the North American Benthological Society 25(3):664-676. http://dx.doi. org/10.1899/0887-3593(2006)25[664:EOSAHC]2.0.CO:2

Myers, M. F., and G. F. White. 1993. The challenge of the Mississippi flood. Environment: Science and Policy for Sustainable Development 35(10):6-35. http://dx.doi.org/10.1080/00139157.1$\underline{993.9929131}$

Nannini, M. A., J. Goodrich, J. M. Dettmers, D. A. Soluk, and D. H. Wahl. 2012. Larval and early juvenile fish dynamics in main channel and backwater lake habitats of the Illinois River ecosystem. Ecology of Freshwater Fish 21(4):499-509. http://dx. doi.org/10.1111/j.1600-0633.2012.00568.x

Natural Resources Conservation Service. 2012. Assessment of the effects of conservation practices on cultivated cropland in the Upper Mississippi River basin. U.S. Department of Agriculture, Natural Resources Conservation Service, Washington, DC, USA. [online] URL: https://www.nrcs.usda.gov/Internet/FSE DOCUMENTS/ stelprdb1042093.pdf

Nelson, J. C., A. Redmond, and R. E. Sparks. 1994. Impacts of settlement on floodplain vegetation at the confluence of Illinois and Mississippi Rivers. Transactions of the Illinois State Academy of Science 87(3-4):117-133.

Newton, T. J., S. J. Zigler, J. T. Rogala, B. R. Gray, and M. Davis. 2011. Population assessment and potential functional roles of native mussels in the Upper Mississippi River. Aquatic Conservation-Marine and Freshwater Ecosystems 21(2):122-131. http://dx.doi.org/10.1002/aqc. 1170

Noe, G. B., and C. R. Hupp. 2009. Retention of riverine sediment and nutrient loads by coastal plain floodplains. Ecosystems 12 (5):728-746. http://dx.doi.org/10.1007/s10021-009-9253-5

Norris, F. T. 1997. Where did the villages go? Steamboats, deforestation, and archaeological loss in the Mississippi valley. Pages 73-89 in A. Hurley, editor. Common fields: an environmental history of St. Louis. Missouri Historical Society Press, St. Louis, Missouri, USA.

Ochs, C. A., O. Pongruktham, and P. V. Zimba. 2013. Darkness at the break of noon: phytoplankton production in the Lower Mississippi River. Limnology and Oceanography 58(2):555-568. http://dx.doi.org/10.4319/10.2013.58.2.0555

O'Connell, D., B. Walker, N. Abel, and N. Grigg 2015. The resilience, adaptation and transformation assessment framework: from theory to application. Commonwealth Scientific and Industrial Research Organisation, Dickson, Australian Capital Territory, Australia, . 
Opperman, J. J., R. Luster, B. A. McKenney, M. Roberts, and A. W. Meadows. 2010. Ecologically functional floodplains: connectivity, flow regime, and scale. Journal of the American Water Resources Association 46(2):211-226. http://dx.doi. org/10.1111/j.1752-1688.2010.00426.x

Owens, J. L., and W. G. Crumpton. 1995. Primary production and light dynamics in an Upper Mississippi River backwater. River Research and Applications 11(2):185-192. http://dx.doi. org/10.1002/rrr.3450110208

Peck, J. H., and M. M. Smart. 1986. An assessment of the aquatic and wetland vegetation of the Upper Mississippi River. Hydrobiologia 136:57-75. http://dx.doi.org/10.1007/BF00051504

Pinay, G., V. J. Black, A. M. Planty-Tabacchi, B. Gumiero, and H. Décamps. 2000. Geomorphic control of denitrification in large river floodplain soils. Biogeochemistry 50:163-182. http://dx.doi. org/10.1023/A:1006317004639

Polis, G. A., W. B. Anderson, and R. D. Holt. 1997. Toward an integration of landscape and food web ecology: the dynamics of spatially subsidized food webs. Annual Review of Ecology and Systematics 28:289-316. http://dx.doi.org/10.1146/annurev. ecolsys.28.1.289

Pongruktham, O., and C. Ochs. 2015. The rise and fall of the Lower Mississippi: effects of hydrologic connection on floodplain backwaters. Hydrobiologia 742(1):169-183. http://dx.doi.org/10.1007/ s10750-014-1983-5

Pryor, S. C., R. J. Barthelmie, and J. T. Schoof. 2013. Highresolution projections of climate-related risks for the Midwestern USA. Climate Research 56(1):61-79. http://dx.doi.org/10.3354/ $\underline{\operatorname{cr} 01143}$

Quinlan, A. E., M. Berbés-Blázquez, L. J. Haider, and G. D. Peterson. 2016. Measuring and assessing resilience: broadening understanding through multiple disciplinary perspectives. Journal of Applied Ecology 53(3):677-687. http://dx.doi.org/10.1111/136$\underline{5-2664.12550}$

Quist, M. C., J. S. Tillma, M. N. Burlingame, and C. S. Guy. 1999. Overwinter habitat use of shovelnose sturgeon in the Kansas River. Transactions of the American Fisheries Society 128:522-527. http://dx.doi.org/10.1577/1548-8659(1999)128<0522: OHUOSS>2.0.CO;2

Raibley, P. T., K. S. Irons, T. M. O'Hara, K. D. Blodgett, and R. E. Sparks. 1997. Winter habitats used by largemouth bass in the Illinois River, a large river-floodplain ecosystem. North American Journal of Fisheries Management 17(2):401-412. http://dx.doi. org/10.1577/1548-8675(1997)017<0401:WHUBLB >2.3.CO;2

Raymond, P. A., N.-H. Oh, R. E. Turner, and W. Broussard. 2008. Anthropogenically enhanced fluxes of water and carbon from the Mississippi River. Nature 451:449-452. http://dx.doi.org/10.1038/ nature06505

Reid, F. A., J. R. Kelley, Jr., T. S. Taylor, and L. H. Fredrickson. 1989. Upper Mississippi valley wetlands - refuges and moist-soil impoundments. Pages 181-202 in L. M. Smith, R. L. Pederson, and R. M. Kaminski, editors. Habitat management for migrating and wintering waterfowl in North America. Texas Tech University Press, Lubbock, Texas, USA.
Remo, J. W. F., N. Pinter, and R. Heine. 2009. The use of retroand scenario-modeling to assess effects of $100+$ years of river engineering and land-cover change on Middle and Lower Mississippi River flood stages. Journal of Hydrology 376 (3-4):403-416. http://dx.doi.org/10.1016/j.jhydrol.2009.07.049

Resilience Alliance. 2010. Assessing resilience in social-ecological systems: workbook for practitioners. Version 2.0. Resilience Alliance. [online] URL: http://www.resalliance.org/3871.php

Richardson, W. B., E. A. Strauss, L. A. Bartsch, E. M. Monroe, J. C. Cavanaugh, L. Vingum, and D. M. Soballe. 2004. Denitrification in the Upper Mississippi River: rates, controls, and contributions to nitrate flux. Canadian Journal of Fisheries and Aquatic Sciences 61:1102-1112. http://dx.doi.org/10.1139/ $\underline{\text { 004-062 }}$

Richardson, W. B., S. J. Zigler, and M. R. Dewey. 1998. Bioenergetic relations in submerged aquatic vegetation: an experimental test of prey use by juvenile bluegills. Ecology of Freshwater Fish 7(1):1-12. http://dx.doi.org/10.1111/j.1600-0633.1998. $\underline{\mathrm{tb} 00167 . \mathrm{x}}$

Ries, P., N. R. De Jager, S. J. Zigler, and T. J. Newton. 2016. Spatial patterns of native freshwater mussels in the Upper Mississippi River. Freshwater Science 35:934-947. http://dx.doi.org/10.1086/686670

Robinson, C. T., K. Tockner, and J. V. Ward. 2002. The fauna of dynamic riverine landscapes. Freshwater Biology 47(4):661-677. http://dx.doi.org/10.1046/j.1365-2427.2002.00921.x

Rosen, R. A., D. C. Hales, and D. G. Unkenholz. 1982. Biology and exploitation of paddlefish in the Missouri River below Gavins Point Dam. Transactions of the American Fisheries Society 111:216-222. http://dx.doi.org/10.1577/1548-8659(1982)111<216: BAEOPI $>2.0 . \mathrm{CO} ; 2$

Sass, G. G., T. R. Cook, K. S. Irons, M. A. McClelland, N. N. Michaels, T. M. O'Hara, and M. R. Stroub. 2010. A markrecapture population estimate for invasive silver carp (Hypophthalmichthys molitrix) in the La Grange Reach, Illinois River. Biological Invasions 12(3):433-436. http://dx.doi. org/10.1007/s10530-009-9462-Z

Sass, G. G., C. Hinz, A. C. Erickson, N. N. McClelland, M. A. McClelland, and J. M. Epifanio. 2014. Invasive bighead and silver carp effects on zooplankton communities in the Illinois River, Illinois, USA. Journal of Great Lakes Research 40(4):911-921. http://dx.doi.org/10.1016/j.jglr.2014.08.010

Scheffer, M., and E. H. van Nes. 2007. Shallow lakes theory revisited: various alternative regimes driven by climate, nutrients, depth and lake size. Hydrobiologia 584:455-466. http://dx.doi. org/10.1007/s10750-007-0616-7

Schiemer, F., and T. Hein. 2008. The ecological significance of hydraulic retention zones. Pages 405-420 in P. J. Wood, D. M. Hannah, and J. P. Sadler, editors. Hydroecology and ecohydrology: past, present, and future. John Wiley and Sons, Chichester, West Sussex, United Kingdom. http://dx.doi.org/10.1002/9780470010198. ch21

Schilling, K. E., K.-S. Chan, H. Liu, and Y.-K. Zhang. 2010. Quantifying the effect of land use land cover change on increasing discharge in the Upper Mississippi River. Journal of Hydrology 387(3-4):343-345. http://dx.doi.org/10.1016/j.jhydrol.2010.04.019 
Schoof, R. 1980. Environmental impact of channel modification. Water Resources Bulletin 16(4):697-701. http://dx.doi.org/10.1111/ j.1752-1688.1980.tb02451.x

Schorg, A. J. 2014. Potential plant response to a seasonal drawdown on Navigation Pool 18 of the Upper Mississippi River. Thesis. Western Illinois University, Macomb, Illinois, USA.

Schramm, H. L., and M. A. Eggleton. 2006. Applicability of the flood-pulse concept in a temperate floodplain river ecosystem: thermal and temporal components. River Research and Applications 22(5):543-553. http://dx.doi.org/10.1002/rra.921

Schramm, H. L., Jr., and B. S. Ickes. 2016. The Mississippi River: a place for fish. Pages 3-34 in Y. Chen, D. Chapman, J. Jackson, D. Chen, Z. Li, J. Kilgore, Q. Phelps, and M. A. Eggleton, editors. Fishery Resources, Environment, and Conservation in the Mississippi and Yangtze (Changjiang) River Basins. American Fisheries Society Symposium 84. American Fisheries Society, Bethesda, Maryland, USA.

Seagle, H. H., Jr., J. C. Hutton, and K. S. Lubinski. 1982. A comparison of benthic invertebrate community composition in the Mississippi and Illinois Rivers, Pool 26. Journal of Freshwater Ecology 1(6):637-650. http://dx.doi.org/10.1080/02705060.1982.9664085

Sheaffer, W. A., and J. G. Nickum. 1986a. Backwater areas as nursery habitats for fishes in Pool 13 of the Upper Mississippi River. Hydrobiologia 136:131-149. http://dx.doi.org/10.1007/ $\underline{\mathrm{BF} 00051510}$

Sheaffer, W. A., and J. G. Nickum. 1986b. Relative abundance of macroinvertebrates found in habitats associated with backwater area confluences in Pool 13 of the Upper Mississippi River. Hydrobiologia 136:113-119. http://dx.doi.org/10.1007/BF00051508

Sheehan, R. J., W. M. Lewis, and L. R. Bodensteiner. 1994. Winter habitat requirements and overwintering of riverine fishes. Southern Illinois University, Carbondale, Illinois, USA. [online] URL: http://opensiuc.lib.siu.edu/fiaq reports/8

Shields, F. D., Jr. 1995. Fate of Lower Mississippi River habitats associated with river training dikes. Aquatic Conservation: Marine and Freshwater Ecosystems 5:97-108. http://dx.doi.org/10.1002/ aqc. 3270050203

Sietman, B. E., S. D. Whitney, D. E. Kelner, K. D. Blodgett, and H. L. Dunn. 2001. Post-extirpation recovery of the freshwater mussel (Bivalvia: Unionidae) fauna in the upper Illinois River. Journal of Freshwater Ecology 16(2):273-281. http://dx.doi. org/10.1080/02705060.2001.9663813

Sluis, W., and J. Tandarich. 2004. Siltation and hydrologic regime determine species composition in herbaceous floodplain communities. Plant Ecology 173(1):115-124. http://dx.doi. org/10.1023/B:VEGE.0000026335.44232.1c

Smith, R. V., J. D. Stafford, A. P. Yetter, M. M. Horath, C. S. Hine, and J. P. Hoover. 2012. Foraging ecology of fall-migrating shorebirds in the Illinois River valley. PLOS ONE 7(9):e45121. http://dx.doi.org/10.1371/journal.pone.0045121

Solomon, L. E., R. M. Pendleton, J. H. Chick, and A. F. Casper. 2016. Long-term changes in fish community structure in relation to the establishment of Asian carps in a large floodplain river. Biological Invasions 18(10):2883-2895. http://dx.doi.org/10.1007/ s10530-016-1180-8
Sparks, R. E. 1995. Need for ecosystem management of large rivers and their floodplains: these phenomenally productive ecosystems produce fish and wildlife and preserve species. BioScience 45(3):168-182. http://dx.doi.org/10.2307/1312556

Sparks, R. E., P. B. Bayley, S. L. Kohler, and L. L. Osborne. 1990. Disturbance and recovery of large floodplain rivers. Environmental Management 14(5):699-709. http://dx.doi.org/10.1007/ $\underline{\mathrm{BF} 02394719}$

Sparks, R. E., J. C. Nelson, and Y. Yin. 1998. Naturalization of the flood regime in regulated rivers: the case of the upper Mississippi River. BioScience 48(9):706-720. http://dx.doi. org/10.2307/1313334

Spink, A., and S. Rogers. 1996. The effects of a record flood on the aquatic vegetation of the Upper Mississippi River System: some preliminary findings. Hydrobiologia 340(1-3):51-57. http:// dx.doi.org/10.1007/BF00012734

Stafford, J. D., M. M. Horath, A. P. Yetter, C. S. Hine, and S. P. Havera. 2007. Wetland use by Mallards during spring and fall in the Illinois and central Mississippi River valleys. Waterbirds 30 (3):394-402. http://dx.doi.org/10.1675/1524-4695(2007)030[0394: WUBMDS]2.0.CO;2

Starrett, W. C. 1971. A survey of the mussels (Unionacea) of the Illinois River: a polluted stream. Illinois Natural History Survey Bulletin 30:267-403.

Steuer, J. J., T. J. Newton, and S. J. Zigler. 2008. Use of complex hydraulic variables to predict the distribution and density of unionids in a side channel of the Upper Mississippi River. Hydrobiologia 610(1):67-82. http://dx.doi.org/10.1007/s10750-008-9423$\underline{\mathrm{Z}}$

Swanson, W., N. R. De Jager, E. Strauss, and M. Thomsen. 2017. Effects of flood inundation and invasion by Phalaris arundinacea on nitrogen cycling in an Upper Mississippi River floodplain forest. Ecohydrology 10:e1877. http://dx.doi.org/10.1002/eco.1877

Tabacchi, E., D. L. Correll, R. Hauer, G. Pinay, A.-M. PlantyTabacchi, and R. C. Wissmar. 1998. Development, maintenance and role of riparian vegetation in the river landscape. Freshwater Biology 40:497-516. http://dx.doi.org/10.1046/j.1365-2427.1998.00381. $\underline{\mathrm{x}}$

Theiling, C. H., C. Korschgen, H. De Haan, T. Fox, J. Rohweder, and L. Robinson 2000. Habitat needs assessment for the Upper Mississippi River: technical Report. U.S. Geological Survey, La Crosse, Wisconsin, USA.

Theiling, C. H., R. J. Maher, and R. E. Sparks. 1996. Effects of variable annual hydrology on a river regulated for navigation: Pool 26, upper Mississippi River system. Journal of Freshwater Ecology 11(1):101-114. http://dx.doi.org/10.1080/02705060.1996.9663498

Theiling, C. H., and J. M. Nestler. 2010. River stage response to alteration of Upper Mississippi River channels, floodplains, and watersheds. Hydrobiologia 640(1):17-47. http://dx.doi.org/10.1007/ s10750-009-0066-5

Thompson, D. 1973. Feeding ecology of diving ducks on Keokuk Pool, Mississippi River. Journal of Wildlife Management 37 (3):367-381. http://dx.doi.org/10.2307/3800128 
Thomsen, M., K. Brownell, M. Groshek, and E. Kirsch. 2012. Control of reed canarygrass promotes wetland herb and tree seedling establishment in Upper Mississippi River floodplain forest. Wetlands 32:543-555. http://dx.doi.org/10.1007/s13157-012-0289-5

Tockner, K., D. Pennetzdorfer, N. Reiner, F. Schiemer, and J. V. Ward. 1999. Hydrological connectivity, and the exchange of organic matter and nutrients in a dynamic river-floodplain system (Danube, Austria). Freshwater Biology 41:521-535. http://dx.doi. org/10.1046/j.1365-2427.1999.00399.x

Tucker, J. K., and C. Theiling. 1999. Freshwater mussels. Pages 11-1-11-14 in K. S. Lubinski and C. Theiling, editors. Ecological status and trends of the Upper Mississippi River System 1998: a report of the Long Term Resource Monitoring Program. U.S. Geological Survey, Upper Midwest Environmental Sciences Center, La Crosse, Wisconsin, USA.

Tucker, J. K., C. H. Theiling, K. D. Blodgett, and P. A. Thiel. 1993. Initial occurrences of zebra mussels (Dreissena polymorpha) on freshwater mussels (Family Unionidae) in the upper Mississippi River system. Journal of Freshwater Ecology 8 (3):245-251. http://dx.doi.org/10.1080/02705060.1993.9664860

Tucker, J. L., C. H. Theiling, and J. B. Camerer. 1996. Utilization of backwater habitats by unionid mussels (Bivalvia: Unionidae) on the Lower Illinois River and in Pool 26 of the Upper Mississippi River. Transactions of the American Fisheries Society 89:113-122.

Turner, R. E., and N. N. Rabalais. 2003. Linking landscape and water quality in the Mississippi River basin for 200 years. BioScience 53(6):563-572. http://dx.doi.org/10.1641/0006-3568 (2003)053[0563:LLAWQI]2.0.CO;2

Twedt, D. J. 2013. Foraging habitat for shorebirds in southeastern Missouri and its predicted future availability. Wetlands 33:667-678. http://dx.doi.org/10.1007/s13157-013-0422-0

Upper Mississippi River Restoration Program (UMRR). 2015. Enhancing restoration and advancing knowledge of the Upper Mississippi River. U.S. Army Corps of Engineers, Rock Island, Illinois, USA.

U.S. Army Corps of Engineers (USACE). 2011. Upper Mississippi River System ecosystem restoration objectives 2009. USACE, Washington, DC, USA. [online] URL: http://www.mvr.usace. army.mil/Portals/48/docs/Environmental/EMP/UMRR_Ecosystem Restoration Objectives 2009.pdf

U.S. Army Corps of Engineers (USACE). 2016. Regulating works project draft supplemental environmental impact statement. USACE, St. Louis, Missouri, USA.

U.S. Fish and Wildlife Service (USFWS). 2015. Upper Mississippi River economic assessment part 1: 60 county assessment. Division of Economics, USFWS, Falls Church, Virginia, USA.

Vonbank, J. A., H. M. Hagy, and A. F. Casper. 2016. Energetic carrying capacity of riverine and connected wetlands of the upper Illinois River for fall-migrating waterfowl. American Midland Naturalist 176(2):210-221. http://dx.doi.org/10.1674/0003-0031-176.2.210

Wahl, D. H., J. Goodrich, M. A. Nannini, J. M. Dettmers, and D. A. Soluk. 2008. Exploring riverine zooplankton in three habitats of the Illinois River ecosystem: where do they come from?
Limnology and Oceanography 53(6):2583-2593. http://dx.doi. org/10.4319/10.2008.53.6.2583

Walker, B., C. S. Holling, S. R. Carpenter, and A. Kinzig. 2004. Resilience, adaptability and transformability in social-ecological systems. Ecology and Society 9(2):5. http://dx.doi.org/10.5751/ ES-00650-090205

Walker, B., and D. Salt. 2012. Resilience practice: building capacity to absorb disturbances and maintain function. Island, Washington, DC, USA. http://dx.doi.org/10.5822/978-1-61091-231-0

Ward, J. V., K. Tockner, F. Schiemer, J. B. Layzer. 1999. Biodiversity of floodplain river ecosystems: ecotones and connectivity. River Research and Applications 15(1-3):125-139. http://dx.doi.org/10.1002/(SICI)1099-1646(199901/06)15:1/3<125:: AID-RRR523>3.0.CO;2-E

Watson, C. C., D. S. Biedenharn, and C. R. Thorne. 2013. Analysis of the impacts of dikes on flood stages in the Middle Mississippi River. Journal of Hydraulic Engineering 139(10):1071-1078. http://dx.doi.org/10.1061/(ASCE)HY.1943-7900.0000786

WEST Consultants Inc. 2000. Upper Mississippi River and Illinois waterway cumulative effects study. Department of the Army, Corps of Engineers, Rock Island, Illinois, USA.

Wilcox, D. B., E. L. Stefanik, D. E. Kelner, M. A. Cornish, D. J. Johnson, I. J. Hodgins, S. J. Zigler, and B. L. Johnson. 2004. Improving fish passage through navigation dams on the Upper Mississippi River. U.S. Army Corps of Engineers, Washington, DC, USA.

Wildhaber, M. L., P. J. Lamberson, and D. L. Galat. 2003. A comparison of measures of riverbed form for evaluating distributions of benthic fishes. North American Journal of Fisheries Management 23(2):543-557. http://dx.doi.org/10.1577/1548-8675 (2003)023<0543:ACOMOR>2.0.CO;2

Williamson, C. J., and J. E. Garvey. 2005. Growth, fecundity, and diets of newly established silver carp in the middle Mississippi River. Transactions of the American Fisheries Society 134 (6):1423-1430. http://dx.doi.org/10.1577/T04-106.1

Wlosinski, J. H., J. T. Rogala, T. W. Owens, K. L. Dalrymple, D. Busse, C. N. Strauser, and E. Atwood. 2000. Response of vegetation and fish during an experimental drawdown in three pools, Upper Mississippi River. U.S. Geological Survey, La Crosse, Wisconsin, USA.

Yin, Y. 1998. Flooding and forest succession in a modified stretch along the upper Mississippi River. River Research and Applications 14:217-225. http://dx.doi.org/10.1002/(SICI)1099-1646 (199803/04)14:2<217::AID-RRR499>3.0.CO;2-S

Zigler, S. J., M. R. Dewey, B. C. Knights, A. L. Runstrom, and M. T. Steingraeber. 2003. Movement and habitat use by radiotagged paddlefish in the upper Mississippi River and tributaries. North American Journal of Fisheries Management 23(1):189-205. http://dx.doi.org/10.1577/1548-8675(2003)023<0189:MAHUBR>2.0. $\mathrm{CO} ; 2$

Zigler, S. J., T. J. Newton, J. J. Steuer, M. R. Bartsch, and J. S. Sauer. 2008. Importance of physical and hydraulic characteristics to unionid mussels: a retrospective analysis in a reach of large river. Hydrobiologia 598(1):343-360. http://dx.doi.org/10.1007/ s10750-007-9167-1 